\title{
nutrients
}

ISSN 2072-6643

www.mdpi.com/journal/nutrients

Review

\section{Transcultural Diabetes Nutrition Algorithm (tDNA): Venezuelan Application}

Ramfis Nieto-Martínez ${ }^{1}$, Osama Hamdy ${ }^{2, *}$, Daniel Marante ${ }^{3}$, María Inés Marulanda ${ }^{4}$, Albert Marchetti ${ }^{5,6}$, Refaat A. Hegazi ${ }^{7}$ and Jeffrey I. Mechanick ${ }^{8}$

1 Department of Physiology, School of Medicine, Universidad Centro-Occidental "Lisandro

Alvarado", Cardio-Metabolic Unit, Barquisimeto 3001, Venezuela; E-Mail: nietoramfis@gmail.com

2 Joslin Diabetes Center, Harvard University, Boston, MA 02215, USA

3 Endocrinology Service, Centro Médico Docente "La Trinidad", Caracas 1080A, Venezuela;

E-Mail: daniel.marante@gmail.com

4 Internal Medicine Department, Centro Médico “Guerra Méndez”, Valencia 2001, Venezuela;

E-Mail: mariainesmarulanda@gmail.com

5 MedERA, Inc., New York, NY 10019, USA; E-Mail: albertmarchetti@yahoo.com

6 Department of Preventive Medicine and Community Health, University of Medicine and Dentistry of New Jersey, Newark, NJ 07101, USA

7 Abbott Nutrition International, Columbus, OH 43219, USA; E-Mail: refaat.hegazi@abbott.com

8 Division of Endocrinology, Diabetes, and Bone Disease, Icahn School of Medicine at Mount Sinai, New York, NY 10029, USA; E-Mail: jeffreymechanick@gmail.com

* Author to whom correspondence should be addressed; E-Mail: osama.hamdy@joslin.harvard.edu; Tel. +1-617-309-2400; Fax: +1-617-309-2712.

Received: 12 December 2013; in revised form: 18 January 2014 / Accepted: 23 January 2014 / Published: 2 April 2014

Abstract: Medical nutrition therapy (MNT) is a necessary component of comprehensive type 2 diabetes (T2D) management, but optimal outcomes require culturally-sensitive implementation. Accordingly, international experts created an evidence-based transcultural diabetes nutrition algorithm (tDNA) to improve understanding of MNT and to foster portability of current guidelines to various dysglycemic populations worldwide. This report details the development of tDNA-Venezuelan via analysis of region-specific cardiovascular disease (CVD) risk factors, lifestyles, anthropometrics, and resultant tDNA algorithmic modifications. Specific recommendations include: screening for prediabetes (for biochemical monitoring and lifestyle counseling); detecting obesity using Latin American cutoffs for waist circumference and Venezuelan cutoffs for BMI; prescribing MNT to people with 
prediabetes, T2D, or high CVD risk; specifying control goals in prediabetes and T2D; and describing regional differences in prevalence of CVD risk and lifestyle. Venezuelan deliberations involved evaluating typical food-based eating patterns, correcting improper dietary habits through adaptation of the Mediterranean diet with local foods, developing local recommendations for physical activity, avoiding stigmatizing obesity as a cosmetic problem, avoiding misuse of insulin and metformin, circumscribing bariatric surgery to appropriate indications, and using integrated health service networks to implement tDNA. Finally, further research, national surveys, and validation protocols focusing on CVD risk reduction in Venezuelan populations are necessary.

Keywords: diabetes; T2D; prediabetes; nutrition; MNT

\section{Introduction}

At present, 346 million people worldwide have diabetes mellitus. It has been estimated that the prevalence of type 2 diabetes mellitus (T2D) will increase more in Latin America (65\%) than worldwide (54\%) between 2010 and 2030 [1]. In Venezuela, at least 1.7 million people suffer from T2D; and, considering only people with impaired fasting glucose, prediabetes prevalence in the country has been reported in four different regions with the number varying between $1.0 \%$ and $18.6 \%$ [2-4]. Moreover, the prevalence of uncontrolled T2D (A1c $\geq 7 \%$ ) in Venezuela is 76\%, one of the highest in Latin America [5]. In order to lessen the burden of these epidemic conditions, proper prevention and treatment interventions must be implemented.

Clinical practice guidelines (CPG) are evidence-based tools designed to assist in standardizing and improving the care of people with prediabetes and T2D [6]. Although generally useful, CPG rarely include ethnic, cultural, and/or socially-specific application cascades, which compromises their applicability and portability to diverse patient settings. In addition, the laborious task of interpreting relatively large amounts of CPG text limits their utility. In Venezuela, for example, the population is ethnically composed of Black, White, Amerindian, and mostly mixed people, geographically stratified in eight regions, with $11.2 \%$ living in rural communities [7]. As a result, there are salient differences in lifestyle and dietary habits, patterns of physical activity, food availability, medical resources, and clinical practices within the country. These issues must be considered prior to any innovative process to improve diabetes care, such as the proposed Latin America Diabetes Association (ALAD) CPG that convey culturally-adapted recommendations from various international diabetes organizations [8].

Likewise, a transcultural Diabetes Nutrition Algorithm (tDNA) has been developed by an international group of expert healthcare professionals in response to the challenges mentioned above. Initially, a composite template was constructed based on extant diabetes CPG from major professional societies in North America and Europe [6]. Then, specific cultural factors that can influence the development and management of T2D were identified and a methodology created to transculturalize the template algorithm on a global scale [6]. The present report represents the current stage of tDNA adaptation in Venezuela, whereby a specific culture and locale will create its own version based on epidemiological, physiological, nutritional, and pathological parameters, as well as body composition and lifestyle 
characteristics that are unique to that locale. Thus, we describe herein the Venezuelan tDNA application (Figure 1) and prepare it for eventual validation protocols.

Figure 1. Transcultural diabetes nutrition algorithm for prediabetes and type 2 diabetes_-Venezuelan Application.

\section{ACTIONS}

(1) Ethno-cultural Lifestyle Input

1) Geographic location and 2) ethno-cultural classification

2 Latin America Modified FINDRISK Score and /or Prediabetes and T2D Diagnosis See Comments.

\section{Other Individual Risk Factors and/or Comorbid Conditions}

Family history of premature cardiovascular disease, high-risk dietary patterns, less than recommended physical activity, BMI/NC over normal local ranges, hypertension, dyslipidemia, any cardiovascular event, any liver disease, microalbuminuria, chronic kidney disease, risky alcohol intake, any sleep disturbance, and/or any chronic illness.

\section{General Recommendations}

Counseling about physical activity, healthy eating, and smoking cessation consistent with current clinical practice guidelines or evidence (Table 2, 3, 5, 7 and Figure2) and glycemiatargeted specialized nutrition (GTSN) as supplementation for undernutrition or as replacement for overweight or obesity consistent with options and strategies (Table 6)

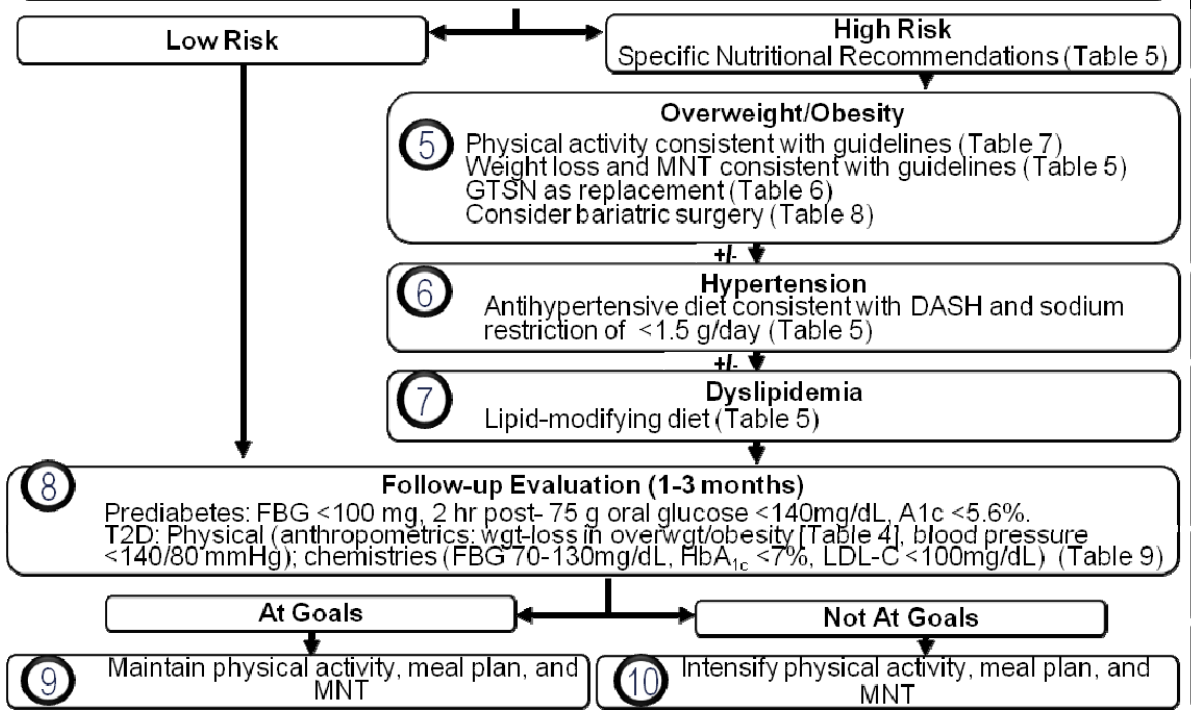

\section{COMMENTS}

Location (Venezuela), ethnicity, and culture individualize recommendations. Inputs will perform other areas of the algorithm.

Prediabetes is established by: $\mathrm{IFG}=100-125 \mathrm{mg} / \mathrm{dL}$; IGT $=140-199 \mathrm{mg} / \mathrm{dL}$; and $/ 0 \mathrm{r} \mathrm{HbA} \mathrm{Hc}_{1 \mathrm{c}}=5.7 \%-6.4 \%$. Diabetes is established by: FPG $>126 \mathrm{mg} / \mathrm{dL}$; casual PG $>200 \mathrm{mg} / \mathrm{dL} ; 2$-hour OGTT $>200 \mathrm{mg} / \mathrm{dL}: \mathrm{HbA}_{1}$ $6.5 \%$. $\left(\mathrm{Hb}_{1}\right.$ alone is not recommended to diagnose diabetes.)

Anthropometrics include weight. BMI, WC according to local values. (Tables 4 )

Excessive daily alcohol consumption is defined as $>2$ drinks for $m e n$ and $>1$ drink for women.

Insufficient physical activity is $<30 \mathrm{~min} /$ day and $/$ or $<5$ days/week.

Individual risk and comorbid conditions direct lifestyle interventions for improved glycemic control and decreased risks for progression, complications, and mortality.

Low-risk patients with prediabetes or type 2 diabetes have no adverse conditions other than an impaired glycemic profile and should follow established general recommendations for lifestyle interventions plus nutritional therapy guidelines. High-risk patients have 1 isk facto reduce progression, complications, and mortality.

When obesity, hypertension, and dyslipidemia complicate prediabetes and diabetes, interventions are additive and intensified.

Nutritional management of cardiometabolic risk factors (obesity, dyslipidemia, hypertension, inflammation) is similar and consistently included in locally adapted Mediterranean diet recommendations. (Table s 2, 5 and Figure 2). Nutritional recommendations from most scientific organizations are complimentary.

Hypertension $=$ blood pressure $>140 / 80 \mathrm{~mm} \mathrm{Hg}$. $2.4 \mathrm{~g} \mathrm{Na}^{*}=6 \mathrm{~g}$ salt $(\sim 1$ teaspoon $)$

$1.5 \mathrm{~g} \mathrm{Na}+=3.7 \mathrm{~g}$ salt $(\sim 2 / 3$ teaspoon)

Follow-up evaluation is scheduled according to patient needs and local practice. Goals are different for prediabetes and diabetes.

\section{Transcultural Factors for Venezuela}

Risk factors for non-communicable diseases (NCDs), both non-modifiable (genetics, gender, and age) and modifiable (improper dietary habits, sedentary lifestyle, smoking, psychological stress, and excess alcohol intake) can be expressed through metabolic/pathophysiological changes (hypertension, dyslipidemia, obesity, prediabetes, and metabolic syndrome). These processes contribute to a composite cardiovascular disease (CVD) risk. Moreover, these biologically determined factors are influenced by personal behavior, governmental policies, socio-economic factors (poverty, urbanization, and globalization), culture, politics, and both the inherent structure and unique dynamics of the target population [9]. Preventive interventions should take into account the biological characteristics and "societal risk conditions" of each population [10], justifying the need for a tDNA application. 


\subsection{Geographic, Demographic, Cultural, and Regional Characteristics of Venezuela}

The Bolivarian Republic of Venezuela is a Caribbean country located in the northern section of South America. It is a federalist nation that consists of a capital district and federal agency, 23 states, and 335 municipalities. The estimated population in 2011 was 27,150,095 inhabitants, with an equal proportion of male $(49.7 \%)$ and female $(50.3 \%)$ residents [7]. Venezuela has experienced demographic changes that are typical for societies in economic transition. The country's population is aging. In 2010, life expectancy at birth was 74.3 years. Sixty-six percent of the population was between 15 and 64 years old, 27.6\% under 14 years, and $6.4 \%$ over 64 years [11]. Venezuela is divided into eight geographic regions: Capital, Central, Western, North-Eastern, Guayana, Andes, Zulia and the Llanos (Plains) [7]. Each region has some particularities regarding geography, climate, natural resources, population density, urban/rural proportion, food availability, and typical food and meal-based eating patterns, which can influence the recommendations for CVD and T2D prevention and treatment.

\subsection{Non-Communicable Diseases in Latin America and Venezuela}

Non-communicable diseases (NCDs), including cancer, CVD, diabetes, and chronic respiratory conditions, have been the leading cause of mortality and morbidity in the Region of the Americas, accounting for 3.9 million (77\%) of a total of 5.1 million deaths in 2007 . Of these 3.9 million deaths, 1.5 million (38\%) were due to cardiovascular disease (CVD) and 232,000 (6\%) were due to diabetes [10]. In September 2011, the United Nations General Assembly acknowledged that NCDs constitute one of the major challenges to development in the 21 st century and addressed its prevention and control as a global priority [12].

Venezuelan trends in NCDs have both similarities and differences with respect to other developing countries. The Global Health Observatory Data Repository reported that in 2008 the age-standardized mortality from NCDs in Venezuela was 433 per 100,000 inhabitants, lower than the Region of the Americas (455) and total worldwide figures (573). However, in adults, aged 30-70 years, CVD- and diabetes-related mortality was 200 per 100,000, higher than the Region of the Americas (169) [13]. In the Venezuelan population older than 25 years compared with the Region, elevated fasting plasma glucose in men (11.1\% vs. 11.5\%) and women (10.9\% vs. 9.9\%) was similar, raised blood pressure in men $(37.1 \%$ vs. $26.3 \%)$ and women $(25,4 \%$ vs. $19.7 \%)$ was higher and obesity in men $(26.6 \%$ vs. $23.5 \%)$ and women (34.8\% vs. 29.7\%) also was higher [13].

Latin America experienced a 14\% drop in CVD between 2000 and 2009; however, this trend varied from one country to another. A study comparing the trend of coronary heart disease mortality between the years 1970 and 2000 in 10 Latin American countries found a decrease in Argentina; less pronounced decreases in Brazil, Chile, Cuba, and Puerto Rico; and increases in Mexico, Costa Rica, Ecuador, and Venezuela [14]. The absolute number of deaths due to heart disease in Venezuela rose between 2006 (24,997 deaths, $20.5 \%$ of total, 94.2 per 100.000 inhabitants) and 2009 (27,353 deaths, 20.3\% of total, 94.2 per 100.000 inhabitants). Similarly, the number of deaths due to diabetes in this period increased from 7181 deaths (5.9\% of total, 26.6 per 100,000 inhabitants) in 2006 to 8822 deaths (6.5\% of total, 31.1 per 100,000 inhabitants) in 2009 [13]. 
Investigating putative risk factors responsible for CVD trends, a study conducted in four Latin American countries found that classic factors like high cholesterol, smoking, hypertension, high body mass index (BMI), and family history of coronary heart disease together accounted for $76 \%$ of cases of myocardial infarction (MI) in Venezuela [15]. These and other risk factors for MI were identified in the INTERHEART Latin American Study, including persistent psychological stress, family history of hypertension, T2D, smoking, and abdominal obesity. Abdominal obesity, smoking, and dyslipidemia were responsible for $88 \%$ of attributable MI risk. On the other hand, daily consumption of fruits and vegetables and regular exercise were associated with risk reduction [16]. Studies linking dietary habits and CVD in Venezuela have shown important disparities among different populations. In Warao Indians, for example, eating habits and intense physical activity inherent in their culture are associated with a low CVD risk profile and normal BMI, blood pressure, plasma glucose, plasma insulin, homeostatic model assessment (HOMA), uric acid, and healthy lipids, including a high HDL-C [17]. In contrast, more than $50 \%$ of the individuals in a study sample from the second largest city in Venezuela (Maracaibo) had a BMI $>25 \mathrm{~kg} / \mathrm{m}^{2} ; 64 \%$ of women had central obesity (defined as waist-to-hip ratio $>0.8$ for women and $>1$ for men); $34 \%$ of men and $28 \%$ and women had high fat ingestion; $36 \%$ of men had high levels of triglycerides and VLDL-C; and $41 \%$ of women and $30 \%$ of men had decreased levels of HDL-C [18]. These differences and trends illustrate the need to incorporate complex cultural and lifestyle parameters into any therapeutic strategy intended for implementation at the population or individual level.

\subsection{Healthcare System in Venezuela}

The Region of the Americas is characterized by highly fragmented health services, which leads to restricted access, poor technical quality, irrational and inefficient use of available resources, unnecessary increases in production costs, and low user satisfaction [10]. In 2003, a Cuban Medical Mission (Misión "Barrio Adentro") was implemented in Venezuela by agreement between Cuban and Venezuelan governments. Numerous primary care centers were established throughout the country and were staffed by Cuban doctors who were directly supervised by their own directors. Although this attempt was initially welcomed as a means to expand access, the Cuban network was kept operationally separate from the pre-existing public health structure, which ultimately increased fragmentation. Moreover, despite good intentions, these programs operated during a period of neutral and/or negative trends of NCDs deaths, cited in some of the above epidemiologic studies. Now, the physical and administrative separations between the Cuban medical mission and ordinary public health services could compromise broad implementation of tDNA. However, with government approval, the primary health network could possibly apply tDNA and increase the utilization of MNT in most social sectors of the population. This strategy recognizes that, like in many other areas of the world, healthcare coverage in private and public settings is different, necessitating different modalities of tDNA implementation.

\subsection{Cardio-Metabolic Comorbidities and Related Risk Factors: Venezuelan Disparities by Gender, Region, Ethnicity, and Population (Urban vs. Rural)}

A national population survey to investigate the prevalence of CVD and lifestyle risk factors has not been performed in Venezuela for the past 10 years, according to WHO 2012 reported statistics [13]. 
In order to document regional disparities in the prevalence of CVD risk factors in Venezuela, a comprehensive literature search from apparently unbiased population-based surveys and registries was conducted. The search was performed using the MEDLINE, SCIELO, LILACS, Revencyt, BIREME, ScIENTI, LIVECS and PERIóDICA bibliographic databases. Literature not indexed, such as white papers, government publications, and conference proceedings, was selected and included if considered appropriate. Studies were classified according to the size of the sampled population (all state, all city, municipalities, and smaller samples) and the studied region of the country. The prevalence of individual cardio-metabolic components in Venezuela by regions is shown in Table 1.

Two well-designed cross-sectional studies have investigated the prevalence of various cardio-metabolic risk components in specific regions of Venezuela. The first estimated the prevalence of metabolic syndrome and its association with demographic and clinical factors in 3108 subjects over 20 years of the representative state of Zulia. The age-adjusted prevalence of metabolic syndrome and atherogenic dyslipidemia was $31.2 \%$ and $24.1 \%$, respectively. The most frequent metabolic syndrome features were low HDL-C (65\%), abdominal obesity (43\%), and hypertension (38\%). In addition, metabolic syndrome prevalence was lower in Amerindian (17\%) compared to Black (27\%), White (33\%) and mixed (37\%) men, but no differences were found among women [3]. The study also reported that black Hispanics had worse CVD risk profiles than mixed Hispanics, with higher blood pressure, higher fasting blood glucose, increased abdominal obesity, and low HDL cholesterol [19]. The second study, CARMELA, was designed to assess the prevalence of CVD risk factors, carotid plaques, and carotid intima-media thickness in 11,150 individuals, 25-64 years old, living in seven major Latin America cities (Barquisimeto, Venezuela; Bogota, Colombia; Buenos Aires, Argentina; Lima, Peru; Mexico City, Mexico; Quito, Ecuador; and Santiago de Chile, Chile). Comparatively, Barquisimeto (Lara State in the Western region of Venezuela) had a high prevalence of metabolic syndrome (25.8\%, ranked 2nd), hypertension (24.7\%, ranked 2nd) and obesity (25.1\%, ranked 3rd); but the prevalence was low for diabetes $(6.0 \%$, ranked 5 th), hypercholesterolemia $(5.7 \%$, ranked 7 th), and smoking $(21.8 \%$, ranked 7 th) [20].

\subsection{Physical Activity in Venezuela}

Physical inactivity causes $5.8 \%$ of the burden of coronary heart disease and $7.2 \%$ of the burden of T2D [21]. Worldwide, $31.1 \%$ of adults are physically inactive. This number is higher in the Americas (43.3\%) [22]. In Lara state (Venezuela), for example, a study in 1399 adolescents reported that only $17.3 \%$ of boys and $7.5 \%$ of girls were physically active (at least $60 \mathrm{~min}$ of physical activity per day on at least five days per week) [23].

Generally, throughout the country, the most popular sport is baseball, although in recent years soccer has gained popularity. Jogging and dancing, mainly in groups, have also become more prevalent. Although Venezuela is geographically diverse, differences in climate and topography have little effect on the type of physical activity that is performed. On the other hand, concerns about public safety may limit activities as crime has become more rampant in Venezuela, now among the Latin American countries with high rates of crime. In men 20-59 years old, violence was the leading cause of death, accounting for $36.5 \%$ of mortalities in 2006 and 38.2 in 2009 [13]. 
Table 1. Prevalence of adult cardio-metabolic components in eight regions of Venezuela.

\begin{tabular}{|c|c|c|c|c|c|c|c|c|c|c|c|c|}
\hline \multirow[b]{2}{*}{ Region } & \multirow[b]{2}{*}{ Obesity (\%) } & \multirow[b]{2}{*}{ Diabetes (\%) } & \multirow{2}{*}{$\begin{array}{c}\text { Prediabetes } \\
\text { (\%) }\end{array}$} & \multirow{2}{*}{$\begin{array}{c}\text { Hypertension } \\
\text { (\%) }\end{array}$} & \multicolumn{5}{|c|}{ Dyslipidemia (\%) } & \multirow{2}{*}{$\begin{array}{c}\text { Metabolic } \\
\text { Syndrome (\%) }\end{array}$} & \multirow{2}{*}{$\begin{array}{c}\text { Physical } \\
\text { Inactivity } \\
(\%) \\
\end{array}$} & \multirow[b]{2}{*}{ Typical Foods } \\
\hline & & & & & $\begin{array}{c}\text { High } \\
\text { Cholesterol } \\
\end{array}$ & High LDL & Low HDL & $\begin{array}{c}\text { High } \\
\text { Triglycerides } \\
\end{array}$ & $\begin{array}{l}\text { Atherogenic } \\
\text { Dyslipidemia }\end{array}$ & & & \\
\hline Capital & $\begin{array}{l}35.0 \mathrm{U}, \mathrm{M}^{*, \mathrm{a}} \\
{[24]} \\
30.0 \mathrm{U}, \mathrm{M}^{*, \mathrm{a}} \\
{[24]}\end{array}$ & $\begin{array}{c}9.5 \mathrm{U}, \mathrm{M}^{*}, \mathrm{a} \\
{[25]} \\
8.0 \mathrm{U}, \mathrm{M}^{*} \\
{[26]} \\
6.7 \mathrm{U}, \mathrm{O}^{*, a} \\
{[27]}\end{array}$ & $\begin{array}{c}9.0 \mathrm{U}, \mathrm{M}^{*, \mathrm{a}} \\
{[25]} \\
10.0 \mathrm{U}, \mathrm{M}^{*} \\
{[26]}\end{array}$ & $\begin{array}{c}34.0 \mathrm{U}, \mathrm{M}^{*} \\
{[26]} \\
43.4 \mathrm{U}, \mathrm{O}^{*, a} \\
{[27]}\end{array}$ & & $\begin{array}{c}51.6 \mathrm{U}, \mathrm{O}^{*, a} \\
{[27]} \\
33.0 \mathrm{U}, \mathrm{O}^{\mathrm{a}} \\
{[28]}\end{array}$ & $\begin{array}{c}81.1 \mathrm{U}, \mathrm{O}^{*, \mathrm{a}} \\
{[27]} \\
56.0 \mathrm{U}, \mathrm{O}^{*, \mathrm{a}} \\
{[25]} \\
42.9 \mathrm{U}, \mathrm{M}^{*, \mathrm{a}} \\
{[26]} \\
44.0 \mathrm{U}, \mathrm{O}^{\mathrm{a}}[28]\end{array}$ & $\begin{array}{l}43.0 \mathrm{U}, \mathrm{M}^{*, \mathrm{a}}[25] \\
31.4 \mathrm{U}, \mathrm{M}^{*}[26] \\
51.3 \mathrm{U}, \mathrm{O}^{*, \mathrm{a}}[27] \\
34.0 \mathrm{U}, \mathrm{O}^{\mathrm{a}}[28]\end{array}$ & & 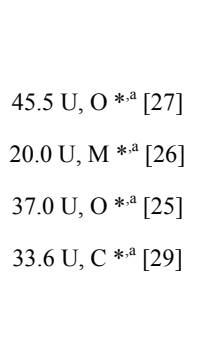 & $\begin{array}{c}31.5 \mathrm{U}, \mathrm{O} \\
{[30]} \\
\text { Ma: } 9.0, \\
\text { Fe: } 34.0 \\
\text { U, O [31] }\end{array}$ & $\begin{array}{l}\text { Roasted or stewed chicken, beef } \\
\text { or fish. With rice, pasta and } \\
\text { salad. Italian, French and } \\
\text { Portuguese influence }\end{array}$ \\
\hline Central & $\begin{array}{c}39.0 \mathrm{U}, \mathrm{O} \\
{[32]}\end{array}$ & $\begin{array}{c}9.0 \mathrm{U}, \mathrm{O} \\
{[32]}\end{array}$ & & $28.1 \mathrm{U}, \mathrm{O}[32]$ & $59.0 \mathrm{U}, \mathrm{O}[32]$ & $25.0 \mathrm{U}, \mathrm{O}[32]$ & $90.0 \mathrm{U}, \mathrm{O}[32]$ & $51.0 \mathrm{U}, \mathrm{O}[32]$ & & & & \\
\hline Western & $\begin{array}{c}25.1 \mathrm{U}, \mathrm{C} * \\
{[20]} \\
26.7 \mathrm{U}, \mathrm{M} * \\
{[33]}\end{array}$ & $\begin{array}{c}6.0 \mathrm{U}, \mathrm{C} * \\
{[2]} \\
11.0 \mathrm{U}, \mathrm{M} * \\
{[33]}\end{array}$ & $\begin{array}{c}15.8 \mathrm{U}, \mathrm{M}^{*} \\
{[33]} \\
1.0 \mathrm{U}, \mathrm{C} * \\
{[2]}\end{array}$ & $\begin{array}{c}23.6 \mathrm{U}, \mathrm{C} * \\
{[34]} \\
24.7 \mathrm{U}, \mathrm{C} * \\
{[20]} \\
29.0 \mathrm{UR}, \mathrm{S} * \\
{[35]} \\
28.3 \mathrm{U}, \mathrm{M} * \\
{[33]}\end{array}$ & $\begin{array}{c}5.7 \mathrm{U}, \mathrm{C} *[20] \\
24.8 \mathrm{U}, \mathrm{M} * \\
{[33]}\end{array}$ & $\begin{array}{c}26.0 \mathrm{U}, \mathrm{M} * \\
{[33]}\end{array}$ & $68.7 \mathrm{U}, \mathrm{M} *[33]$ & $49.0 \mathrm{U}, \mathrm{M} *[33]$ & $\begin{array}{c}36.9 \mathrm{U}, \mathrm{M}^{*} \\
{[33]}\end{array}$ & $\begin{array}{l}34.9 \mathrm{U}, \mathrm{M} *[33] \\
25.8 \mathrm{U}, \mathrm{C} *[20]\end{array}$ & & $\begin{array}{l}\text { Sheep, goat and rabbit meat. } \\
\text { Cheese and milk whey }\end{array}$ \\
\hline Andeans & $\begin{array}{c}12.1 \mathrm{R}, \mathrm{M} * \\
{[4]} \\
24.3 \mathrm{U}, \mathrm{M} * \\
{[33]}\end{array}$ & $\begin{array}{c}8.6 \mathrm{R}, \mathrm{M} * \\
{[4]} \\
14.9 \mathrm{U}, \mathrm{M} * \\
{[33]}\end{array}$ & $\begin{array}{c}18.6 \mathrm{U}, \mathrm{M} * \\
{[4]} \\
4.5 \mathrm{U}, \mathrm{M} * \\
{[33]}\end{array}$ & $\begin{array}{c}25.4 \mathrm{R}, \mathrm{M} * \\
\quad[36] \\
34.4 \mathrm{U}, \mathrm{M} * \\
{[33]}\end{array}$ & $\begin{array}{l}11.6 \mathrm{U}, \mathrm{M} *[33] \\
22.1 \mathrm{R}, \mathrm{M} *[36] \\
33.0 \mathrm{U}, \mathrm{C} *[37]\end{array}$ & $\begin{array}{c}14.6 \mathrm{U}, \mathrm{M} * \\
{[33]} \\
13.9 \mathrm{R}, \mathrm{M} * \\
{[36]}\end{array}$ & $\begin{array}{l}43.1 \mathrm{R}, \mathrm{M} *[36] \\
69.6 \mathrm{U}, \mathrm{M} *[33] \\
76.0 \mathrm{U}, \mathrm{C} *[37]\end{array}$ & $\begin{array}{l}45.0 \mathrm{R}, \mathrm{M} *[36] \\
39.5 \mathrm{U}, \mathrm{M} *[33] \\
56.0 \mathrm{U}, \mathrm{C} *[37]\end{array}$ & $\begin{array}{c}16.8 \mathrm{R}, \mathrm{M} * \\
{[36]} \\
26.6 \mathrm{U}, \mathrm{M} * \\
{[33]}\end{array}$ & $\begin{array}{l}26.7 \mathrm{U}, \mathrm{R} *[4] \\
38.5 \mathrm{U}, \mathrm{C} *[37] \\
27.6 \mathrm{U}, \mathrm{M} *[38] \\
23.8 \mathrm{U}, \mathrm{M} *[33]\end{array}$ & & $\begin{array}{l}\text { Potatoes, wheat and tuber. Beef, } \\
\text { sheep and chicken meat. Fish } \\
\text { (cultured trout). Similar to other } \\
\text { Andean regions }\end{array}$ \\
\hline
\end{tabular}


Table 1. Cont.

\begin{tabular}{|c|c|c|c|c|c|c|c|c|c|c|c|c|}
\hline Zulia & $\mathrm{ND}$ & $\begin{array}{c}\text { Ma:7.8, } \\
\text { Fe:7.4 S, U * } \\
{[3]}\end{array}$ & $\begin{array}{c}\text { Ma: 19.6, } \\
\text { Fe: } 14.9 \mathrm{~S}, \mathrm{U} \text { * } \\
{[3]}\end{array}$ & $\begin{array}{c}36.9 \mathrm{U}, \mathrm{C} * \\
{[39]}\end{array}$ & $\begin{array}{c}39.3 \mathrm{U}, \mathrm{O}[40] \\
\text { Ma: } 40.2, \\
\text { Fe: } 46.0 \mathrm{U}, \mathrm{O} \\
\quad[41]\end{array}$ & & 65.3 UR, S [3] & $\begin{array}{c}32.3 \text { UR, S [3] } \\
55.9 \text { U, O [40] } \\
\text { Ma: } 47.8 \\
\text { Fe: } 12.2 \text { U, O [41] }\end{array}$ & 26.0 UR, S * [3] & $\begin{array}{l}31.2 \mathrm{~S}, \mathrm{U} *[3] \\
32.1 \mathrm{U}, \mathrm{O}[40]\end{array}$ & $\begin{array}{c}71.3 \mathrm{UR}, \mathrm{S} \text { * } \\
{[3]}\end{array}$ & $\begin{array}{l}\text { Platain (patacón), fried } \\
\text { wheat cake }\end{array}$ \\
\hline North-Eastern & ND & ND & $\mathrm{N} \mid \mathrm{D}$ & $\mathrm{ND}$ & $\mathrm{ND}$ & $\mathrm{ND}$ & ND & ND & ND & ND & ND & $\begin{array}{c}\text { River and sea fish, } \\
\text { seafood, shrimp, lobster. } \\
\text { Tuber as yam, potatoes, } \\
\text { ocumo. Sea food rice } \\
\text { (paella) }\end{array}$ \\
\hline Guayana & ND & ND & ND & ND & ND & $\mathrm{ND}$ & ND & ND & ND & ND & ND & $\begin{array}{c}\text { Guayanés cheese, fried } \\
\text { fish with arepa, rice, salad } \\
\text { and sliced plantain } \\
\text { (tajadas) }\end{array}$ \\
\hline Llanos & $\mathrm{ND}$ & ND & ND & ND & ND & $\mathrm{ND}$ & ND & ND & ND & ND & ND & $\begin{array}{l}\text { Beef, deer, chiguire, turtle } \\
\text { and lapa meat. Barbecue } \\
\text { with cachapas, cheese and } \\
\text { milk cream }\end{array}$ \\
\hline
\end{tabular}

Sample: state (S); municipality (M); city (C); other populations (O); urban (U); rural (R), (less than 2500 inhabitants); urban + rural (UR); random sample (*); Male (Ma), Female (Fe); no data (ND); abstract published in congress ( ${ }^{\mathrm{a}}$ ). Exclusion criteria included studies in children and adolescents studies with hypertension prevalence estimated by METS definition, studies including only subjects older than 60 year, studies evaluating hospitalized patients, physical activity measured by methods different than International Questionnaire of Physical Activity (IPAQ) or validated methods and studies with unclear methodology. In reference [41] and [32], data from total population were corrected. 
Sadly, the actions of government to improve public safety and reduce crime have been largely ineffective. The scarcity of outdoor safety has limited opportunities to exercise regularly, as only a minority of individuals can afford or even like attending a gym. Shopping malls have become favorite places where families spend time, but activities in malls tend to be more social, sporadic, and interrupted by numerous food stands with unhealthy options. Consequently, physical activity prescribed through tDNA may be restricted to those undertakings that can be done at home or in other safe places.

\subsection{Aspects of Nutrition in Venezuelan (Dietary Habits, Food Availability, Typical Foods, and Their Glycemic Indices)}

In the United States (US) and Europe, there has been a gradual transition towards the consumption of energy-dense, high caloric foods, important drivers of overweight and obesity [42]. In Latin America, this transition has occurred faster, beginning in Venezuela in the mid-1990s when "under and over" nutrition coexisted. A similar phenomenon also exists in other areas of the world, e.g., India [43] and Pakistan, where economies are in transition. Venezuelan nutritional data is generally not published in peer review journals. However, data from surveys published by the National Statistics Institute in Venezuela have shown that caloric consumption has increased 27\% from 2202 calories in 1998 to 2790 calories in 2009, which is above the minimum 2700-calories recommendation of the FAO [44]. A follow-up survey of food consumption, in which intake was calculated by household consumer purchases of certain foods (apparent consumption), reported changes between 2003 and 2010 [44]. Although there was a slight increase in the apparent consumption of legumes (8\%) and fruits (12\%); a greater decrease of other healthy foods such as vegetables $(-20.2 \%)$ and fish $(-28.4 \%)$, especially fresh fish $(-43.4 \%)$ was observed. An increase of apparent consumption of meats $(2.9 \%)$ especially poultry $(15.8 \%)$ and a decrease of cereals $(-5.9 \%)$ and roots $(-9.2 \%)$ has also been noted. The survey further reported that $60 \%$ of the Venezuelan population eats three times a day and $39 \%$ eats four or five times. A study in 243 women aged 12-45 from Lara state revealed more obesity in adults (30\%) than adolescents (7\%), and more low weight $(21 \%)$ in adolescents than adults $(3 \%)$. Using 24 -h recall, deficiencies in protein intake $(72.0 \%)$, calories $(58.1 \%)$, calcium $(34.7 \%)$, zinc $(20.9 \%)$, copper, $(13.3 \%)$, folate (41.5\%), Vitamin B6 (19.8\%) and Vitamin C (62.6\%) were detected. Using food frequency questionnaire, a low intake of fruits $(40 \%)$ and vegetables (14\%) was uncovered [45].

In Venezuela, foreign dietary habits (food acculturation) from Spain, Portugal, and Italy (Mediterranean diet) along with flavors of China and Japan have increased gastronomic variety. Whereas, indigenous foods such as "casabe" (yuca cake), "arepa" (corn flour, water and salt), and "hallaca" (a mixture of beef, pork, chicken, raisins, capers, and olives wrapped in cornmeal dough, folded within plantain leaves, tied with strings, then boiled or steamed) are still common and have remained unchanged. The national dish, called "pabellón criollo," is a product of miscegenation and contains four basic ingredients: rice, plantain, beef, and black beans [46]. Another typical food, "empanada," comprising fried corn cake stuffed with cheese, beans or meat, and with $322 \mathrm{kcal}$ on average, is broadly consumed. In addition to its popularity, the empanada also has social importance because its sale provides economic support for many families [47]. A modified and larger version of hamburgers called "pepitos" (bread, beef or pork, sauces, fries, cheese) have become very popular in the last 30 years, mostly at dinner. "Sancocho" a soup made with vegetables and beef or hen meat, commonly provides a healthier weekend option. In addition to 
traditional fare, a substantial quantity of processed energy-dense fast food is also consumed in Venezuela. Indeed, $47 \%$ of all fast food eaten in the world is consumed in the Americas Region, most of it in Fast Service Restaurants [48]. Besides autochthon fast foods (arepas, empanadas, pepitos, etc.), many fast food chains, such as McDonalds, Burger King, Wendys, Pizza Hut, KFC, Subway, and others, are now present in Venezuela. See Table 2 for foods common to various regions of the country.

Table 2. Typical and recommended menus of Venezuelan foods.

\begin{tabular}{|c|c|c|c|c|c|}
\hline \multicolumn{2}{|c|}{ Current Typical Day Menu 1} & \multicolumn{2}{|c|}{ Current Typical Day Menu 2} & \multicolumn{2}{|c|}{$\begin{array}{l}\text { Recommended Menu } \\
\text { Mediterranean-Like }\end{array}$} \\
\hline Breakfast & Servings & Breakfast & Servings & Breakfast & Servings \\
\hline \multirow[t]{2}{*}{ Fried empanadas } & 2 units $(200 \mathrm{~g})$ & Fried empanadas & 2 units $(200 \mathrm{~g})$ & Oat with low fat milk & $1 / 2 \operatorname{cup}(120 \mathrm{cc})$ \\
\hline & & & & Low fat milk & $1 / 2$ glass $(120 \mathrm{cc})$ \\
\hline Coffee with milk & 1 cup & Malta & $222 \mathrm{cc}$ & Oat & 1 spoon $(7 \mathrm{~g})$ \\
\hline \multirow[t]{8}{*}{ Sugar } & 1 spoon $(12 \mathrm{~g})$ & & & Sugar & 1 spoon (12 g) \\
\hline & & & & Integral bread & 2 slices $(50 \mathrm{~g})$ \\
\hline & & & & Goat cheese & 6 spoon $(30 \mathrm{~g})$ \\
\hline & & & & Orange slides & 1 unit $(150 \mathrm{~g})$ \\
\hline & & & & Natural fruit juice & 1 glass $(240 \mathrm{cc})$ \\
\hline & & & & Paw & $1 \operatorname{cup}(150 \mathrm{~g})$ \\
\hline & & & & Sugar & $1 / 2$ spoon $(6 \mathrm{~g})$ \\
\hline & & & & Black coffee & 1 cup \\
\hline Lunch & Servings & Lunch & Servings & Lunch & Servings \\
\hline Beef steak & $210 \mathrm{~g}$ & Fried chicken & $210 \mathrm{~g}$ & Black Beans soap & $1 / 2 \operatorname{cup}(180 \mathrm{cc})$ \\
\hline Pasta & 1 cup $(170 \mathrm{~g})$ & White rice & 1 cup $(170 \mathrm{~g})$ & Meat shredded & 1 cup (130 g) \\
\hline $\begin{array}{l}\text { Fried plantain } \\
\text { (Tajada) }\end{array}$ & 1/4 unit (75 g) & $\begin{array}{l}\text { Fried plantain } \\
\text { (Tajada) }\end{array}$ & $1 / 4$ unit $(75 \mathrm{~g})$ & Green (species) & $1 / 4 \operatorname{cup}(10 \mathrm{~g})$ \\
\hline Banana & 1 unit (200 g) & Banana & 1 unit (200 g) & White rice & $1 / 2 \operatorname{cup}(100 \mathrm{~g})$ \\
\hline White bread & 1 unit (35 g) & White bread & 1 unit (35 g) & Mix salad & 3 cup \\
\hline Soda & $\begin{array}{l}1 \text { glass } \\
(240 \mathrm{cc})\end{array}$ & Natural fruit juice & $\begin{array}{l}1 \text { glass } \\
(240 \mathrm{cc})\end{array}$ & Tomato & 1 cup $(80 g)$ \\
\hline Coffee with milk & 1 unit & Melón & $1 \operatorname{cup}(150 \mathrm{~g})$ & Lettuce & 1 cup $(80 \mathrm{~g})$ \\
\hline \multirow[t]{8}{*}{ Sugar } & 1 spoon (12 g) & Sugar & 1 spoon (12 g) & Onion & 1 cup $(80 \mathrm{~g})$ \\
\hline & & & & Avocado & $1 / 4$ unit $(50 \mathrm{~g})$ \\
\hline & & & & Olive Oil & 2 spoon $(7 \mathrm{cc})$ \\
\hline & & & & Cut fruit & $1 \operatorname{cup}(200 \mathrm{~g})$ \\
\hline & & & & Melón & 1 cup $(150 \mathrm{~g})$ \\
\hline & & & & Sugar & $1 / 2$ spoon $(10 \mathrm{~g})$ \\
\hline & & & & Snack & \\
\hline & & & & Salad fruit (Tizana) & 1 cup $(200 \mathrm{~g})$ \\
\hline Dinner & Servings & Dinner & Servings & Dinner & Servings \\
\hline $\begin{array}{c}\text { Arepa with } \\
\text { white cheese }\end{array}$ & $\begin{array}{c}2 \text { unit } \\
(240 \mathrm{~g}) / 60 \mathrm{~g}\end{array}$ & $\begin{array}{l}\text { Arepa with } \\
\text { white cheese }\end{array}$ & $\begin{array}{c}2 \text { unit } \\
(240 \mathrm{~g}) / 60 \mathrm{~g}\end{array}$ & Mix of vegetables & 2 spoon \\
\hline Margarine & 2 slides $(600 \mathrm{~g})$ & Margarine & 2 slides (60 g) & Onion & 1 cup $(80 \mathrm{~g})$ \\
\hline Coffe with milk & 1 cup & Soda & $\begin{array}{l}1 \text { glass } \\
(240 \mathrm{cc})\end{array}$ & Tomato & 1 cup $(80 \mathrm{~g})$ \\
\hline
\end{tabular}


Table 2. Cont.

\begin{tabular}{|c|c|c|c|c|c|}
\hline \multirow[t]{4}{*}{ Sugar } & $\begin{array}{l}1 \text { spoon } \\
(12 \mathrm{~g})\end{array}$ & & & Capsicum & $1 \operatorname{cup}(170 \mathrm{~g})$ \\
\hline & & & & Fish or tuna & $\begin{array}{c}1 \text { slide or } \\
1 \text { cup }(170 \mathrm{~g})\end{array}$ \\
\hline & & & & Arepa & 1 unit (100 g) \\
\hline & & & & Whole fruit & 1 cup (150 g) \\
\hline \multicolumn{2}{|c|}{ Menu Composition } & \multicolumn{2}{|c|}{ Menu Composition } & \multicolumn{2}{|c|}{ Menu Composition } \\
\hline Nutrient & Content & Nutrient & Content & Nutrient & Content \\
\hline Energy (kcal) & 2785 & Energy (kcal) & 3174 & Energy (kcal) & 1734 \\
\hline $\begin{array}{c}\text { Carbs } \\
(\mathrm{g} / \% \text { of Energy })\end{array}$ & $366.5 / 46$ & $\begin{array}{c}\text { Carbs } \\
(\mathrm{g} / \% \text { of Energy })\end{array}$ & $356 / 44$ & $\begin{array}{c}\text { Carbs } \\
(\mathrm{g} / \% \text { of Energy })\end{array}$ & $220.7 / 50$ \\
\hline $\begin{array}{c}\text { Lipid } \\
\text { (g/\% of Energy) }\end{array}$ & $147.2 / 41$ & $\begin{array}{c}\text { Lipid } \\
\text { (g/\% of Energy) }\end{array}$ & $155 / 44$ & $\begin{array}{c}\text { Lipid } \\
\text { (g/\% of Energy) }\end{array}$ & $41.0 / 29$ \\
\hline $\begin{array}{c}\text { Protein } \\
\text { (g/\% of Energy) }\end{array}$ & $104 / 13$ & $\begin{array}{c}\text { Protein } \\
\text { (g/\% of Energy) }\end{array}$ & $93 / 12$ & $\begin{array}{c}\text { Protein } \\
\text { (g/\% of Energy) }\end{array}$ & $126.0 / 21$ \\
\hline Fiber (g) & 17.4 & Fiber $(g)$ & 18.6 & Fiber (g) & 46.2 \\
\hline Cholesterol (mg) & 277 & Cholesterol (mg) & 244 & Cholesterol (g) & 221 \\
\hline Sodium (mg) & 1643 & Sodium (mg) & 1551 & Sodium (mg) & 839 \\
\hline
\end{tabular}

To better understand dietary patterns, food choices, and economics in Venezuela, in 2011, the Central Bank presented results from the IV National Household Budget and Eating Habits Survey [49]. This survey reported that the most frequent breakfast choice is arepa stuffed with cheese and served with coffee. The most common lunch consists of beef steak or fried chicken served with rice or pasta and bananas, along with fruit juice or soda. Dinner is similar to breakfast with arepas stuffed with cheese served with fruit juice or coffee. One in every three people drinks soda with lunch. In addition, $81 \%$ of Venezuelans regularly consume coffee, mostly with breakfast and dinner, and 33\% of coffee consumption occurs before breakfast. These figures are maintained across all social strata [49]. Considering these data, the nutritional composition of two menus representing the typical daily intake of Venezuelans is presented in Table 2 along with a recommended menu.

Although the glycemic index is a useful tool in the nutritional treatment of T2D, a 2006 study reported that only $25 \%$ of health centers in Caracas used the glycemic index for nutritional recommendations [50]. Comparing glucose excursions produced by 50 g glucose (pattern) and its equivalent in Venezuelan food content, the highest glycemic indexes were found in casabe, tapioca (yucca), bread, and potato, followed by banana, arepa, papelón (brown sugar cane), and finally pasta and black beans at the lowest end of the range. Most of the fruits had a glycemic index below 50 [51]. See Table 3.

Alcohol consumption in Venezuela is relatively high. Data from subjects older than 15 years $(69 \%$ of population) have revealed that per capita consumption of pure alcohol (L/year) in Venezuela in 2004 was the highest in Latin America [52]. Using AUDIT scoring in a Venezuelan indigenous population, 87\% of men were found to be problem drinkers, thus establishing one of the highest prevalence rates for problem drinking reported in the worldwide literature [53]. Consumption increased between 1961 and 1981, decreased until 2001, and stabilized between 2001 and 2005. The types of alcohol being consumed include beer (75\%), spirits (24\%), and wine (1\%) [54]. 
The only study assessing salt intake in Venezuela was conducted in Táchira state (Andes Region) through chemical analysis of food portions and reported $2082 \mathrm{mg} /$ day and $1472 \mathrm{mg} /$ day in subjects living at higher and lower altitudes, respectively. Although this consumption is normal, methodological problems in the study and issues related to population sampling limit extrapolation of results [55]. Elevated blood pressure observed in patients with metabolic syndrome may be due to increased reactivity of blood pressure to salt intake [56].

Table 3. Glycemic index of selected Venezuelan foods [51].

\begin{tabular}{cc|cc}
\hline $\begin{array}{c}\text { Carbohydrate } \\
\text { Foods }\end{array}$ & $\begin{array}{c}\text { Glycemic } \\
\text { Index }\end{array}$ & $\begin{array}{c}\text { Carbohydrate } \\
\text { Foods }\end{array}$ & $\begin{array}{c}\text { Glycemic } \\
\text { Index }\end{array}$ \\
\hline Glucose & 100 & Fruits & \\
Common foods & & Banana & 59 \\
Casabe & 118 & Papaya & 50 \\
Tapioca (yuca) & 108 & Pineapple & 41 \\
Bread & 98 & Mango & 36 \\
Arepa & 74 & Tangerine & 36 \\
Brown sugar cane & 71 & Watermelon & 34 \\
Pasta & 59 & Vegetables & \\
Legumes & & Potato & 93 \\
Black beans & 51 & Platain & 78 \\
\hline
\end{tabular}

Glycemic index (GI) ranks carbohydrates according to their effect on blood glucose levels. High GI $\geq 70$; medium GI 56-69; low GI $\leq 55$.

\subsection{Body Composition and Cardio-Metabolic Risk, Genetic, and Ethnic Particularities in}

\section{Venezuelan Population}

Anthropometric measurements (BMI, body fat, and waist circumference) are used to measure body composition and the risk of T2D onset and progression. The optimal cutoff point to detect abdominal obesity may vary based on genetic differences among races. In Latin American subjects, the optimal cutoff value of waist circumference to diagnose abdominal obesity, based on the power to predict excess abdominal visceral adipose tissue, has been reported to be $\geq 94 \mathrm{~cm}$ in men and $\geq 90 \mathrm{~cm}$ in women [57]. On the other hand, the accuracy of BMI in diagnosing obesity is limited. In 13,601 subjects (age 20-79.9 years) from the Third National Health and Nutrition Examination Survey of USA, a BMI between 25 and $30 \mathrm{~kg} / \mathrm{m}^{2}$ may underestimate the prevalence of obesity by $50 \%$ compared with body fat measurements by bioimpedance analysis [58]. A similar assessment in 1375 Venezuelan subjects aged $\geq 18$ years ( $71 \%$ women, $54 \%$ obese) reported that a BMI cutoff of $\geq 30 \mathrm{~kg} / \mathrm{m}^{2}$ has good specificity but misses $21 \%$ of people with excess fat. Consequently, for this segment of the population, the best BMI cutoff to categorize obesity was $27.5 \mathrm{~kg} / \mathrm{m}^{2}$, with a sensitivity of $89.3 \%$ (95\% CI, 87-91) and a specificity of $85.4 \%$ (95\% CI, 81-89) [59]. In lean adolescents, a BMI of $21 \mathrm{~kg} / \mathrm{m}^{2}$, combined with a diet high in saturated fat and a low level of physical activity may be responsible for hyperinsulinemia and dyslipidemia [60]. Therefore, lower values of waist circumference and BMI must be considered in the Venezuelan tDNA application. See Table 4.

Associations between genetic polymorphisms and CVD risk in a population of the Zulia region of Venezuela have been described. The Gly482Ser polymorphism of PGC-1 gene may be associated with 
increased CVD risk in T2D [61]. Also, an apparent association between the G/A UCP-3 genotype with hyperglycemia, hypertension, and increased fat percentage was observed in both sexes, and with dyslipidemia in women [62]. Also in Venezuelan subjects, previous studies have shown that the coexistence of obesity and family history of diabetes may be responsible for the deficit of pancreatic insulin secretion [63]. In men, a positive family history of T2D was responsible for decreased insulin secretion measured by HOMA $\beta$ cell, and disposition index (product of insulin sensitivity and $\beta$-cell function) showed that decreased insulin secretion was not a compensatory response to insulin resistance when obesity and a family history of T2D are concomitant [64]. Indeed, brothers of asymptomatic subjects with T2D showed two times more impaired fasting glucose than control subjects [65]. These findings support the importance of family history of T2D and the presence of obesity when screening for impaired glucose regulation and risk for T2D.

Table 4. Classification of body composition by BMI, waist circumference and disease risk for Venezuelans [57].

\begin{tabular}{ccccc}
\hline \multirow{2}{*}{ Category } & BMI, kg/m & & \multicolumn{2}{c}{ Disease Risk } \\
\cline { 4 - 5 } & & Obesity Class & $\begin{array}{c}\text { WC: } \mathbf{M} \leq \mathbf{9 4} \mathbf{~ c m} \\
\mathbf{F} \leq \mathbf{9 0} \mathbf{~ c m}\end{array}$ & $\begin{array}{c}\mathbf{W C}: \mathbf{M}>\mathbf{9 4} \mathbf{~ c m} \\
\mathbf{F}>\mathbf{9 0} \mathbf{~ c m}\end{array}$ \\
\hline Underweight & $<18.5$ & & & \\
Normal & $18.5-24.9$ & & & \\
Overweight & $25.0-27.4$ & & Increased & High \\
& $27.5-34.9$ & I & High & Very high \\
Obesity & $35.0-39.9$ & II & Very high & Very high \\
& $\geq 40$ & III & Extremely high & Extremely high \\
\hline
\end{tabular}

Body mass index (BMI); female (F); male (M); waist circumference (WC).

Prediabetes screening is hampered by the relative unavailability of appropriate biochemical tests. Diabetes risk scores have become very useful to screen for impaired glucose regulation and occult T2D, the Finnish Diabetes Risk Score (FINDRISC) being the most commonly used [66]. A study to validate FINDRISC as a screening tool for people with impaired glucose regulation in Latin America was performed replacing the original cutoff point of waist circumference with the Latin American cutoff point for subjects from Bogotá (Colombia) and Barquisimeto (Venezuela). Compared with the original, the modified FINDRISC ( $\mathrm{mFR}$ ) score had similar discrimination power to identify impaired glucose regulation in men and performed better in women. The cutoff score for the $\mathrm{mFR}$ to screen men and women with impaired glucose regulation in Barquisimeto was $>14$ [67].

Considering these data, it is proposed: (1) use mFR in Latin America to define subjects requiring OGTT to diagnose prediabetes or occult diabetes; (2) use the Latin America specific cutoff point of waist circumference to detect abdominal obesity; (3) do not rule out intervention in subjects with BMI between 27.5 and $30 \mathrm{~kg} / \mathrm{m}^{2}$, since this population may have greater adiposity and CVD risk; and (4) extend the intervention to all subjects with high CVD risk, not just those with prediabetes or T2D. 


\section{Current Local CPG and Proposed Recommendations}

Therapeutic lifestyle changes (TLCs) are the cornerstone for promoting cardiovascular health and should include achieving a healthy weight, increasing physical activity, reducing stress, avoiding smoking, and promoting anti-atherogenic diets. Unlike drug therapy, TLCs should be promoted at all ages and at all levels of risk, across all levels of prevention. A health professionals' follow-up study, which included more than 42,000 subjects followed for 16 years, showed that five attributes of healthy lifestyle (no smoking, body mass index $<25$, moderate or vigorous physical activity $\geq 30 \mathrm{~min} /$ day, moderate alcohol consumption, and healthy diet) reduced the risk of coronary heart disease by $90 \%$ in subjects not taking medication [68]. Although TLCs are simple and inexpensive interventions, they are followed by only a minority of the population. A study in 153,000 adults reported that only $3 \%$ of the population practices four healthy habits evaluated together (no smoking, healthy weight, five servings of fruits and vegetables a day, and regular physical activity) [69]. Therefore, it is incumbent on health professionals to motivate their patients to achieve TLCs, and a portable, transcultural, and easy-to-use tool such as tDNA may help.

\subsection{Medical Nutrition Therapy (MNT) Recommendations in T2D and Co-Morbidities}

Epidemiologic and clinical data indicate that weight loss through lower energy intake and increased physical activity may decrease T2D risk more than pharmacotherapy [70,71]. Inverse associations with diabetes risk have been found with increased consumption of vegetables [72,73], whole grains [74] and limited consumption of alcohol [75]. Foods with lower glycemic indices also have been associated with improved glycemic control in subjects with diabetes [76]. Recent evidence suggests that coffee consumption may also be associated with a decreased risk for T2D and several other NCDs [77]. Certain dietary patterns also have been inversely associated with T2D and CVD risk. It has been reported that adherence to a Mediterranean-type diet is associated with a lower incidence of T2D even in the absence of changes in body weight or physical activity [78]. More recently, a Mediterranean diet supplemented with extra-virgin olive oil or nuts showed benefits in primary prevention reducing the incidence of major cardiovascular events among persons at high cardiovascular risk [79]. International and national diabetes scientific associations' (ADA/AACE, ALAD, FENADIABETES) recommendations for nutrition and our proposed adaptations are summarized in Table 5. The Mediterranean diet meets most of the requirements of these organizations, promotes control of $\mathrm{T} 2 \mathrm{D}$, and may contribute to the amelioration of other CVD risk factors, including dyslipidemia, obesity, high blood pressure, and inflammation [80,81]. The diet is characterized by abundant plant foods (vegetables, breads, other forms of cereals, potatoes, beans, nuts, and seeds), fresh fruit as dessert, olive oil as the principal source of fat, dairy products (principally cheese and yogurt), fish and poultry in low to moderate amounts, zero to four eggs weekly, occasional red meat, and conservative wine consumption, normally with meals [82].

Although a nutritionist with knowledge of MNT can help to improve outcomes in patients with T2D [83], not all patients have immediate access to their services. Therefore, it is recommended that primary care physicians be involved in the implementation of TLCs and acquire a basic knowledge of nutrition to assist patients in need. Practical implementation of dietary recommendations can be achieved using the Mediterranean food pyramid [82]. The Mayo Clinic version of the Mediterranean 
food pyramid also has the potential to set calorie levels by providing patients with information on the number of servings per food group that should eaten [84] (Figure 2). An example of the Mediterranean diet adapted with typical Venezuelan foods, with their compositions and portions, is presented in Table 2 as a recommendation. The implementation of tDNA in Venezuela should consider providing portable nutritional information through the Mediterranean pyramid with menus adapted to Venezuelan cultures. Any practice or expertise limitation may justify the need for consulting a nutritionist to develop additional tools and programs to support learning and implementation of behavioral changes.

Table 5. ADA/AACE, ALAD, FENADIABETES and proposed major nutrition recommendations for $\mathrm{T} 2 \mathrm{D}$.

\begin{tabular}{|c|c|c|c|c|}
\hline Nutrient $^{a}$ & ADA ${ }^{b} / A A C E[85,86]$ & ALAD [8] & FENADIABETES [87] & Proposed recommendations \\
\hline \multirow{4}{*}{ Calories } & Deficit: $500-1000$ kcal/day; & & & Deficit: $500-1000 \mathrm{kcal} /$ day; \\
\hline & Target: decrease weight by & & Restriction: $25-30$ & Target: weight loss of $5 \%$ in \\
\hline & $5 \%-10 \%$ for overweight and & & Maintenance: $30-35$ & 3 months or $10 \%$ in 6 months for \\
\hline & obese individuals & & & overweight and obese individuals \\
\hline Carbohydrate & $\begin{array}{c}45 \%-65 \% \text { daily energy intake } \\
\text { and not }<130 \text { g/day }\end{array}$ & $40 \%-60 \%$ & $45 \%-65 \%$ & $45 \%-55 \%$ \\
\hline \multirow{3}{*}{ Protein } & \multirow{3}{*}{$15 \%-20 \%$ daily energy intake } & $15 \%-30 \%$ & \multirow{3}{*}{$0.8-1 \mathrm{~g}(80 \% \mathrm{HBV})$} & $15 \%-20 \%$ \\
\hline & & No less than & & $\sin ^{2}(\log (80 \% \mathrm{HRV})$ \\
\hline & & $<1 \mathrm{~g} / \mathrm{kg}$ & & $0.070-1.2 \mathrm{~g} / \mathrm{R}(00 / 0 \mathrm{THD})$ \\
\hline Fat & $20 \%-35 \%$ daily energy intake & $30 \%-45 \%$ & $25 \%-35 \%$ & $25 \%-30 \%$ \\
\hline \multirow{2}{*}{ Saturated fat } & \multirow{2}{*}{$<7 \%$ daily energy intake } & \multirow{2}{*}{$<7 \%$} & \multirow{2}{*}{$7-10 \mathrm{~g} /$ day } & $<7 \%$ \\
\hline & & & & $7-10 \mathrm{~g} /$ day \\
\hline Cholesterol & $<200 \mathrm{mg} /$ day & & $\leq 200 \mathrm{mg} /$ day & $<200 \mathrm{mg} /$ day \\
\hline Fiber & $25-50 \mathrm{~g} /$ day & & $14 \mathrm{~g} / 1000 \mathrm{cal}$ & $\begin{array}{c}25-35 \mathrm{~g} / 1000 \mathrm{cal} \\
(5 \%-10 \% \text { soluble fiber })\end{array}$ \\
\hline Trans fat & Minimize or eliminate & $<1 \%$ & & Minimize or eliminate \\
\hline Sodium $^{\mathrm{c}}$ & $<2300 \mathrm{mg} /$ day & & $1 \mathrm{~g} / 1000 \mathrm{cal}$ & $1 \mathrm{~g} / 1000 \mathrm{cal}$ \\
\hline
\end{tabular}

American Association of Clinical Endocrinologists (AACE); American Diabetes Association (ADA); body mass index (BMI); high


mix of macronutrients and therefore should be based on individualized assessment of current eating patterns, preferences, and metabolic goals; ${ }^{\mathrm{c}}$ Apply other DASH (Dietary Approaches to Stop Hypertension) recommendations in hypertensive subjects [89].

\subsection{Diabetes-Specific Formulas to Facilitate Metabolic Control}

Glycemia-targeted specialized nutrition (GTSN) contain nutrients (maltodextrin, fructose, fiber, soy protein, monounsaturated fatty acids, and antioxidants) that are designed to facilitate glycemic control in subjects with T2D and may be used as part of MNT for calorie replacement in overweight/obese subjects or supplementation for underweight individuals [6,90]. Previous evidence supports the benefits of GTSN, i.e., improving glycemic control and reducing chronic complications related to $\mathrm{T} 2 \mathrm{D}[91,92]$. A structured dietary intervention with meal replacement has also induced weight reduction in patients with diabetes [93]. For example, a study of 5145 overweight/obese subjects with T2D showed that a comprehensive lifestyle intervention, including GTSN as meal replacement, can lead to significant weight loss (i.e., $\geq 5 \%$ ) and maintenance of this loss in more than $45 \%$ of patients at four years [94]. At present, no published data on the use of GTSN in Venezuela are available. While such data are 
gathered in local populations, recommendations drawn directly from the original tDNA template can be implemented [6]. As local data emerge and are assessed by age, disease duration, and T2D complications, perhaps more appropriate cutoff points for A1c can be established to grade glycemic control more precisely and better direct the use of GTSN [95]. See Table 6.

Figure 2. Food pyramid with Mediterranean diet recommendations and caloric goals [84].

\begin{tabular}{|c|c|c|c|c|c|}
\hline & & Sweets & $\leq 75 \mathrm{cals} / \mathrm{d}$ & \multicolumn{2}{|c|}{ Processed swect5 } \\
\hline & & Fats & 3-5 servines/d & \multicolumn{2}{|c|}{ Healthy vils and ouls } \\
\hline & & otein and Dairy & $3-/$ servings/d & \multicolumn{2}{|c|}{ Berns, f sh, lean meats } \\
\hline & & Carbohydrates & $4-8$ servings $/ \mathrm{d}$ & \multicolumn{2}{|c|}{ Wole grains } \\
\hline & & $\begin{array}{l}\text { Fruits and } \\
\text { Vegetables }\end{array}$ & $\begin{array}{l}\text { Unlimited } \\
23 \text { fruits/ and } \\
24 \text { vegetables }\end{array}$ & \multicolumn{2}{|c|}{$\begin{array}{l}W \text { de variety fruits } \\
W \text { de variety veggies }\end{array}$} \\
\hline \multicolumn{6}{|c|}{ Recommendations for Daily Servings at Various Calorie Levels } \\
\hline Food Group & \multicolumn{5}{|c|}{ Starting Caloric Goals and Servings/Day } \\
\hline & 1,200 & 1,400 & 1,600 & 1,800 & 2,000 \\
\hline Vegetables & $\geq 4$ & $\geq 4$ & $\geq 5$ & $\geq 5$ & $\geq 5$ \\
\hline Fruit & $\geq 3$ & $\geq 4$ & $\geq 5$ & $\geq 5$ & $\geq 5$ \\
\hline Carbohydrate & 4 & 5 & 6 & 7 & 8 \\
\hline Protein/Dairy & 3 & 4 & 5 & 6 & 7 \\
\hline Fats & 3 & 3 & 3 & 4 & 5 \\
\hline
\end{tabular}

Table 6. Glycemia-targeted specialized nutrition (GTSN) for the management of prediabetes and diabetes [6].

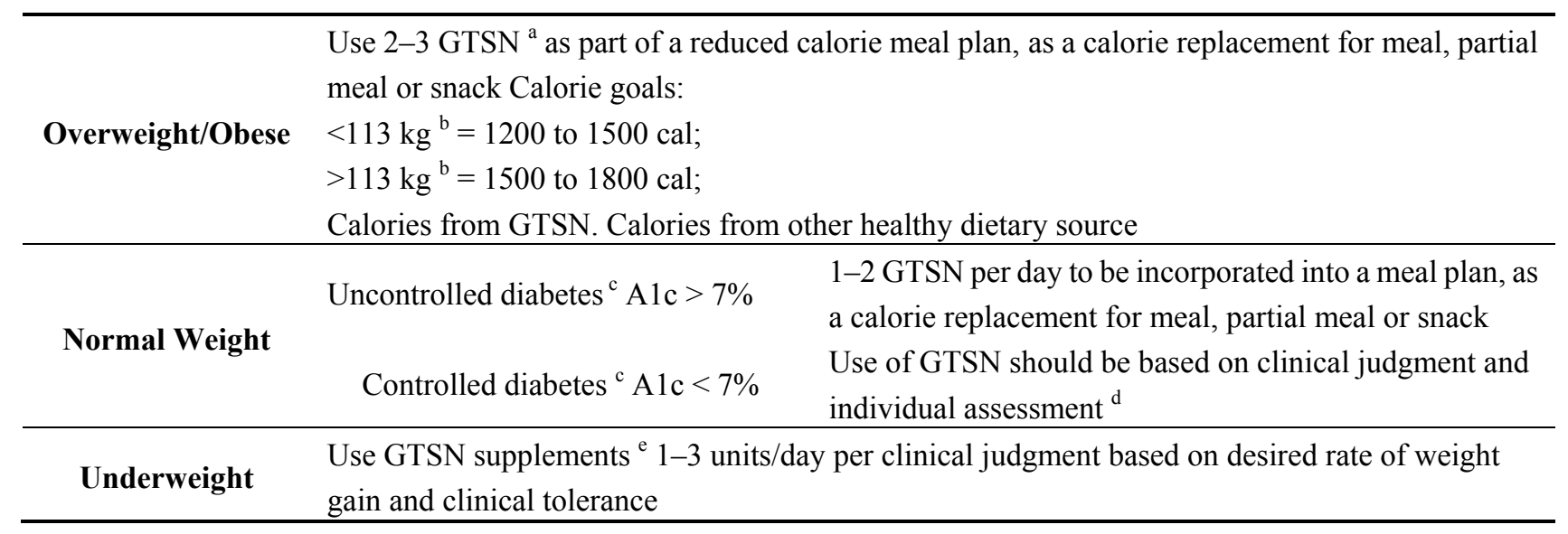

a Glycemia-targeted specialized nutrition (GTSN) are nutritional products used as calorie, partial calorie, or snack replacements in the diet. GTSNs provide approximately 100 to $300 \mathrm{kcal}$ per serving; ${ }^{\mathrm{b}}$ Per Look AHEAD study (113 kg discriminator correlates with $27.5 \mathrm{BMI}) ;{ }^{\mathrm{c}}$ Glycemic targets should be individualized: Middle age and/or without complications (micro and/or macrovascular) and/or disease duration $<10$ year, A1c goal is $6.5 \%-7 \%$. Elderly and/or complications (micro and/or macrovascular) and/or disease duration $>10$ year), A1c goal is $7 \%-8 \%$; ${ }^{\mathrm{d}}$ Individuals who may have muscle mass and/or function loss and/or micronutrient deficiency may benefit from GTSN supplements. Individuals who need support with weight maintenance and/or a healthy meal plan could benefit from GTSN; ${ }^{\mathrm{e}}$ GTSN supplements are complete and balanced nutritional products with $\geq 200$ cal per serving used in addition to a typical meal plan to help promote increased nutritional intake. glycosylated hemoglobin $\mathrm{A}_{1 \mathrm{c}}(\mathrm{A} 1 \mathrm{c})$. 


\subsection{Physical Activity Recommendations}

Physical activity is essential in the prevention and treatment of T2D. Prospective studies in high-risk patients have concluded that regular physical activity is associated with a lower risk of developing T2D. Likewise, after T2D onset, routine physical exertion improves glucose control, slows disease progression, and prevents micro- and macrovascular complications. Benefits can be observed after a single exercise session (acute effect) improving muscular glucose uptake for $48 \mathrm{~h}$ and with regular ongoing exercise (chronic effect) lowering both fasting and postprandial glucose and glycated hemoglobin levels. Although aerobic exercise has been traditionally prescribed for patients with diabetes, resistance training also has benefits, augmenting both strength and insulin-sensitive muscle mass and decreasing cardiovascular risk. A combination of aerobic and resistance exercise provides the greatest benefit in the glycemic management of T2D [96].

Within Venezuela, a study in Zulia state evaluated the effectiveness of physical activity on the components of metabolic syndrome among individuals with prediabetes. In 140 subjects with mean age of 48 years, with BMI of $32.1 \mathrm{~kg} / \mathrm{m}^{2}$, and who were randomly assigned to an intensive lifestyle (ILS, $n=70$ ) intervention group (adapted from the U.S. Diabetes Prevention Program) or standard intervention control $(n=70)$ group for two years, significant improvements from baseline were observed in weight, waist circumference, diastolic blood pressure, triglycerides, HDL-cholesterol, fasting blood glucose, and cardiovascular health scores, ILS group vs. control [97]. Based on these and other similar findings[98], the physical activity recommendations in the Venezuelan tDNA include: (1) encourage at least $30 \mathrm{~min}$ of aerobic exercise five days/week minimally but preferably daily; (2) provide an exercise prescription that includes details for type, amount, duration, and intensity of the recommended exercise; (3) set target heart rate and perceived effort as a measure of intensity; and (4) encourage incorporating non-exercise physical activity into daily life. An exercise prescription for individuals with diabetes and prediabetes with adaptations for Venezuela are presented in Table 7.

\subsection{Bariatric Surgery Indications}

Two published studies have investigated the effect of bariatric surgery in Venezuelan patients. The first compared laparoscopic Roux-en-Y gastric bypass (RYGB) and laparoscopic sleeve gastrectomy (LSG) in 117 obese patients; no differences were found in length of stay, major complications, improvement in co-morbidities, and postoperative weight loss at one year [99]. Laparoscopic-assisted gastric banding can be considered in patients with T2D who have a BMI $>30 \mathrm{~kg} / \mathrm{m}^{2}$ and laparoscopic RYGB for patients with a BMI $>35 \mathrm{~kg} / \mathrm{m}^{2}$ [100]. In the second study, 15 selected patients with T2D and a BMI between 30 and $35 \mathrm{~kg} / \mathrm{m}^{2}$ underwent a laparoscopic RYGB and were followed for one year. T2D remission was achieved in $93 \%$ of patients with significant drops in blood glucose and A1c. Dyslipidemia was controlled in $100 \%$ of patients and hypertension was $83.3 \%$ [101]. According to the International Diabetes Federation, bariatric surgery should be considered an alternative treatment option in patients with a BMI of $30-35 \mathrm{~kg} / \mathrm{m}^{2}$ when diabetes is not adequately controlled by a medical regimen and especially when there are cardiovascular disease risk factors [100]. Recently, the American Society for Metabolic and Bariatric Surgery also noted that bariatric surgery (Gastric banding, LSG and RYBG) can benefit patients with grade 1 obesity based on evidence of clinical effectiveness, cost-effectiveness, 
ethics, and equity as well as the belief that this group should not be excluded from treatment [102]. Since no local bariatric surgery CPGs are available, international guidelines with minor modifications summarized in Table 8 should be considered.

Table 7. Exercise prescription for individuals with diabetes and prediabetes with modifications for Venezuela. Adapted from [85,98].

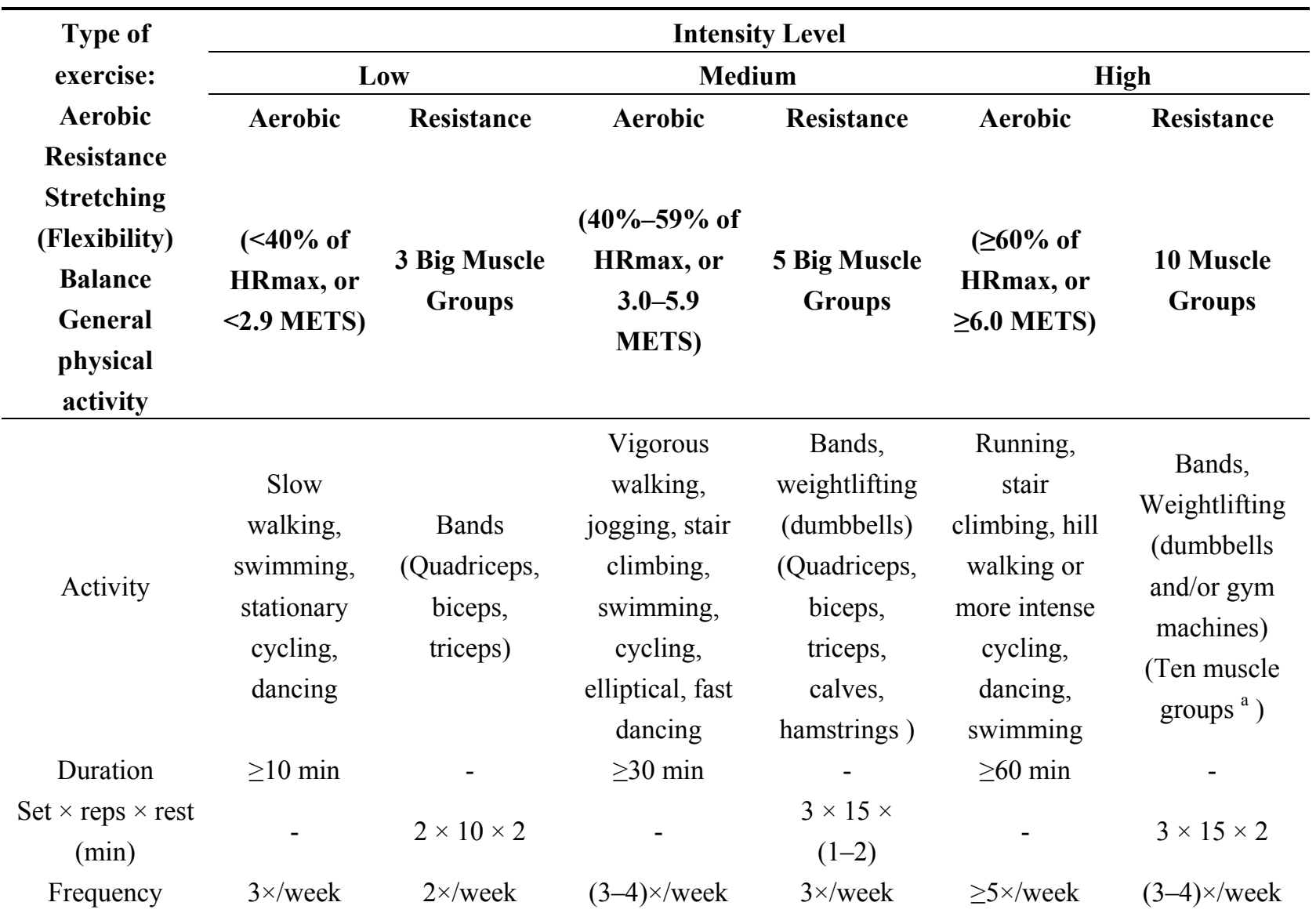

Stretching for maintaining flexibility and range of motion of joints is recommended after each exercise session. This can be achieved by passively (with the aid of the opposite limb, or by another person) or actively (using the agonist-antagonist muscle contraction).

General physical activity: Use the stairs in the workplace. Subjects, who have practiced a sport in the past should be encouraged to take up this activity again after achieving an acceptable fitness level. Pedometer: 3000 to 7000 steps per day (individualized) Place: Select safer places to exercise. Walking or jogging on treadmills, stationary cycling, dancing, elliptical, bands, and weight lifting with dumbbells can be performed at home. Outdoor exercises such as jogging and cycling should be performed in organized groups. Only few options such as weight lifting using machines could require a gym.

The initial intensity level should be selected based on age, presence of comorbidities and/or musculoskeletal limitations and fitness level of each subject. Older, less trained and/or subjects with limited mobility should start exercising at a low intensity level.

Metabolic Equivalent (MET); Patients should be encouraged to achieve an active lifestyle and avoid sedentary living, to facilitate glycemic control and achieve health benefits. All physical activity provides some health benefits. In high CVD risk patients, exercise should be undertaken only after cardiac clearance from a physician. Patients with complications (e.g., stroke, amputation, etc.) will benefit from any physical activity (e.g., aerobics, resistance training, stretching) adapted to their condition and applied towards rehabilitation. In the presence of other complications of T2D (neuropathy, retinopathy, nephropathy, heart disease) exercise should be individualized; ${ }^{\text {a }}$ Ten muscular groups are: quadriceps (front of legs), hamstrings (back of legs), calves, pectorals (chest), lats and trapezium (upper back), deltoids (shoulders), biceps (front of arms), triceps (back of arms), abdomen and obliques (belly) and lower back. 
Table 8. Criteria for bariatric surgery for the management of obesity and/or diabetes $[100,103]$.

\begin{tabular}{l}
\hline \multicolumn{1}{c}{ BMI $\geq \mathbf{4 0} \mathbf{~ k g} / \mathbf{m}^{2}$} \\
\hline BMI $35-39.9 \mathrm{~kg} / \mathrm{m}^{2}$ and an obesity-related comorbidity, such as T2D, coronary heart disease, \\
or severe sleep apnea. \\
\hline BMI $30-34.9 \mathrm{~kg} / \mathrm{m}^{2}$ under special circumstances \\
- When diabetes is not adequately controlled by a medical regimen and especially when there are \\
cardiovascular disease risk factors. \\
\hline - Consideration may be given to laparoscopic-assisted gastric sleeve in patients with T2D who have a \\
BMI $>30 \mathrm{~kg} / \mathrm{m}^{2}$ or Roux-en-Y gastric bypass for patients with a body BMI $>35 \mathrm{~kg} / \mathrm{m}^{2}$ to achieve at least \\
short-term weight reduction. \\
-And for each of the above: \\
Failure to achieve and sustain weight loss after attempts at supervised lifestyle modification for at least \\
six months; \\
Tolerable operative risks; \\
Understanding of operation; \\
Commitment to treatment and long-term follow-up; \\
Acceptance of required lifestyle changes; \\
Diagnostic of psychiatric conditions; \\
Suitable life expectancy.
\end{tabular}

Body mass index (BMI).

\subsection{Follow-Up Evaluation}

The effectiveness of the intervention should be assessed 1-3 months after being implemented. In this version of tDNA, monitoring indicators were specified in case of subjects with prediabetes or diabetes. Thus, the treatment must be maintained if the goals are achieved or otherwise should be intensified.

\section{Factors Affecting TDNA Implementation}

\subsection{Changes in Food Intake, Medical Appointments, and Treatment Adherence during Holidays}

Venezuela is a country where holidays are highly valued. Indeed, a large segment of the population enjoys many days off from work during Christmas, New Years, Carnival, Easter, "summer" or school vacations, and several national holidays which are extended when they occur on Thursdays or Tuesdays. Furthermore, in the past year, a new work law (Ley del Trabajo) was promulgated by the Government, making December 24 and 31 official holidays. This abundance of work-free days may be one of the reasons for the country's high ranking on the scale of "Happiest Countries in the World", despite current macroeconomic worries, extreme political polarization, and above all, very high rates of crime and compromised public safety. During these holidays, a generalized internal and external exodus takes place, mainly by cars and buses. Eateries are commonly associated with gasoline stations and their offerings predominantly include arepas that could contain a large amount of saturated fat. Fast food restaurant chains and tourist facilities, filled with unhealthy food choices, also abound. Moreover, holidays also encourage excessive alcohol consumption, which leads to numerous vehicular accidents and fatalities. Combined, these holiday excursions and improprieties play a significant role in the disruption of healthy lifestyles and adherence to medical advice, therapies, and healthcare visits. 


\subsection{Misconception of Obesity as an Esthetic Problem}

Obesity remains one of the most difficult conditions to treat; simpler and more effective therapies are needed. Additionally, relapse is problematic because of its frequency and severity. Often a diet-resistant state emerges, in which people continue to gain weight despite persistence with their dieting. Prevailing practices for obesity include professional (empiric) and non-approved activities, ranging from simple low caloric dietary applications to use of assorted anti-obesity remedies. Furthermore, the disproportionate number of beauty pageant winners among Venezuelan women has reinforced the notion that beauty has supreme value, slimness being an inherent component of beauty, and any degree of overweightness is socially unacceptable. A large number of beauty centers have proliferated and are often staffed by untrained personnel. Significant amounts of money are spent on beauty treatments as women of all social status hope to improve their physical appearance with cosmetic procedures to plastic surgeries, ranging from botox injections to liposuction and breast implants.

This state of affairs leads to a frivolous view of obesity care that, on the one hand, inflates expectations of medical treatment yet, on the other hand, prompts abandonment of treatment for failure to achieve unrealistic goals. Disenchantment with traditional management also prompts transition to alternative and unproven therapies, most of which have more risks than benefits. Another deleterious effect of this esthetic view is that most insurance companies in Venezuela do not cover expenses for obesity treatment or anti-obesity drugs. In light of these circumstances, implementation and acceptance of a viable tDNA Venezuelan application can help to reinforce recent declarations that obesity is in fact a disease, not just a cosmetic problem [104]. In addition, based on its underlying evidence, tDNA should improve clinical outcomes. Validation of its clinical effectiveness is underway.

\subsection{Misconceptions Surrounding Insulin}

In Venezuela, the central importance of plasma insulin levels may be overstated. Expert groups have defined both metabolic syndrome and PCOS on the grounds of clinical signs or routine well-standardized laboratory measurements (e.g., plasma glucose, HDL-cholesterol, triglycerides, and blood pressure). Only the European Group for the Study of Insulin Resistance (EGIR) included measurements of plasma insulin as one of their criteria to diagnose metabolic syndrome. [105] Furthermore, plasma insulin measurement is not a standardized procedure and results may differ according to the methodology employed. Therefore, the derivation of indexes such a HOMA-IR from plasma glucose and insulin values is not warranted for clinical purposes. Also, it does not seem to be necessary to use plasma insulin measurements to establish the presence of insulin resistance. Family history; the measurement of BMI, waist circumference, distribution of body fat, triglycerides, HDL-cholesterol; and the presence of acanthosis nigricans provide enough information to assess insulin resistance.

Often, physicians may not be aware of the pitfalls of the use of insulin measurements and often order this test. Also, it is observed that the OGTT is performed after a "high-carb" breakfast without using the oral glucose load. In some cases, blood samples are taken every hour or every half hour with serial measurements of blood glucose, plasma insulin and even glycosuria. Since most clinical laboratories are privately owned and do not require a medical order to execute diagnostic testing, a condition exists 
where patients frequently seek out medical attention for "hyperinsulinism". Many times these results are unreliable or even are not elevated.

\subsection{Misuse of Metformin and Other Drugs in the Treatment of Obesity}

Metformin is one of the most popular drugs in Venezuela. As with many drugs in the country, it is being sold without the need for a medical prescription and its price is extremely low in comparison to international prices due to price-control policies of the government. It is a common belief in Venezuela that metformin is an anti-obesity drug or that must be prescribed when plasma insulin levels are elevated. Metformin is self-prescribed and inappropriately prescribed by doctors and non-professional practitioners, and its use often supplants any attempt to initiate and maintain TLCs. A retrospective study in 924 patients attending three health centers showed heterogeneity in the indications of metformin. In one center (University Hospital), metformin was indicated only in patients with T2D. In a non-university center, metformin was used in T2D (24\%) and other conditions such as insulin resistance (34\%), obesity (11\%), impaired glucose tolerance (3\%) and PCOS (2\%). Finally, in a research university setting (Pharmacology Unit), metformin was indicated in T2D (9\%), insulin resistance (68\%), impaired glucose tolerance $(21 \%)$ and PCOS (2\%) [106]. These prescribing practices may also fueled by erroneous interpretations of the Diabetes Prevention Program (DPP) study results [107] and CPGs.

Considering the factors previously mentioned, tDNA implementation is a excellent opportunity to educate physicians in order to: (a) consider obesity as a disease and regulate those individuals, professionals and non-professionals who are treating obesity only from an aesthetic point of view; (b) recommend OGTT as is standardized measuring only fasting plasma glucose levels (not insulin) and $2 \mathrm{~h}$ glucose after a $75 \mathrm{~g}$ glucose load (not after a "high carbo breakfast") and (c) avoid prescribing metformin as an specific "anti-obesity" drug or in subjects with normal glucose regulation. A summary of current and proposed behavior/recommendations introduced as Venezuelan tDNA modifications are presented in Table 9.

Table 9. Summary of current status and proposed tDNA recommendations for Venezuela.

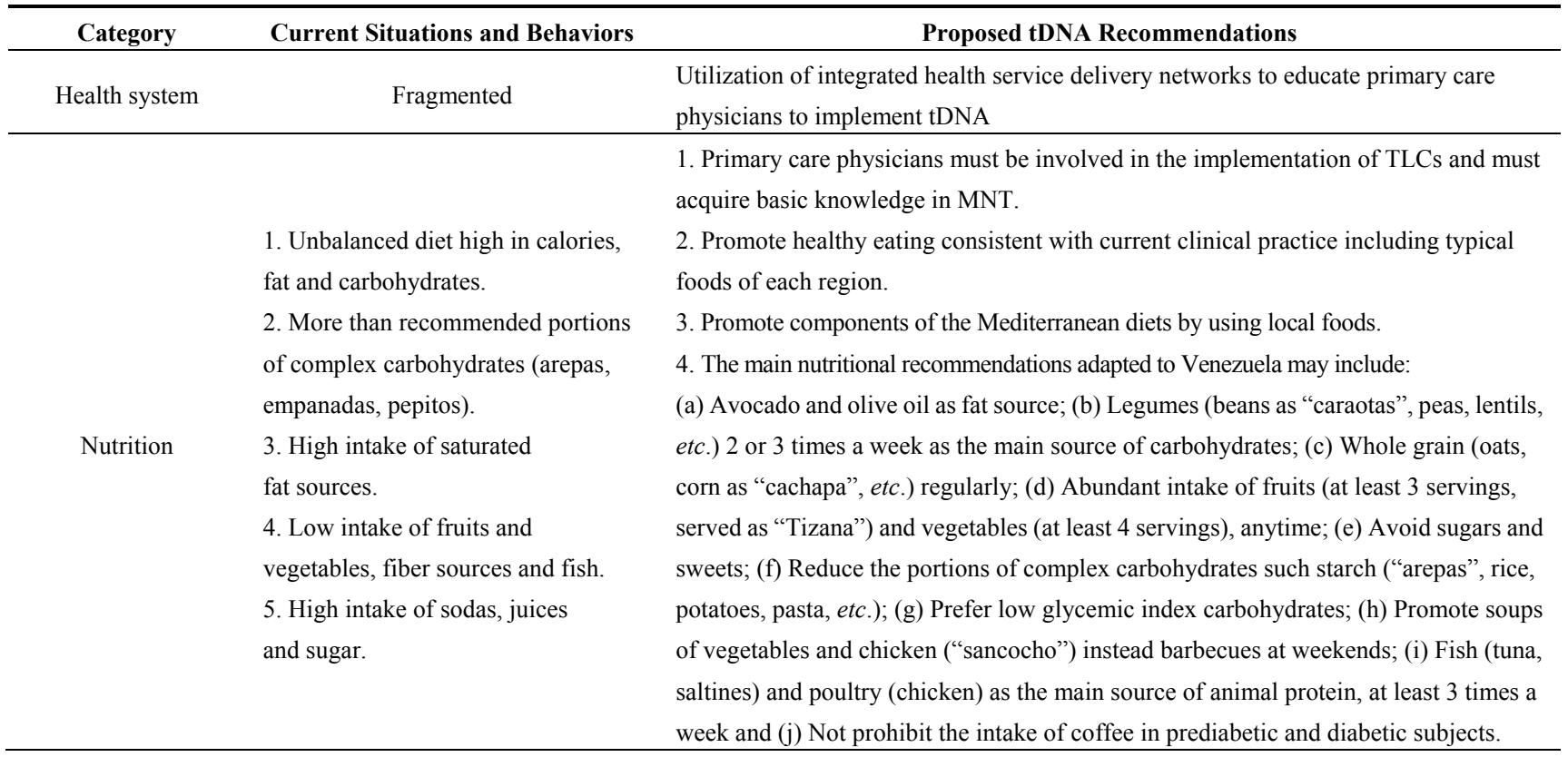


Table 9. Cont.

1. Prescribe physical activity recommendations that include aerobic, resistance, stretching, balance and general physical activity including previous sports practiced, suitable to be done at home and other safe places.

2. Provide patients with an exercise prescription that includes details about the type, amount, duration, and intensity of the recommended exercises.

3. Recommend at least 150 min per week of physical activity (advance to $300 \mathrm{~min}$ per week).

1. High rates of physical inactivity.

Physical activity $\quad 2$. Unsafe public areas can limit physical activity.
4. Sports in groups (dancing, cycling, jogging) may be effective and safer.

5. An example of a plan is presented below:

a. Aerobic: 3 sessions of $30 \mathrm{~min}$ on 3 different days. Pause if $30 \mathrm{~min}$ cannot be achieved consecutively. b. Resistance: 2 sessions of $30 \mathrm{~min}$. Use dumbbells or bands. Appropriate dumbbell weight or band color is allows individual to feel the effort after 15 repetitions. Perform 3 sets of 15 reps for each muscle group with one minute rest between each set. Each set plus rest are about $6 \mathrm{~min}$. The initial muscle groups can be quadriceps, hamstrings, biceps, triceps and calves. Exercise of these 5 muscle groups can be done at home. Time spent to exercise all groups would be $30 \mathrm{~min}(6 \mathrm{~min}$ per muscle group $\times 5$ ). All 10 muscle groups could be exercised in a gym. c. Stretching before and after each exercise session.

\begin{tabular}{|c|c|c|}
\hline $\begin{array}{l}\text { Anthropometry } \\
\text { and body } \\
\text { composition }\end{array}$ & $\begin{array}{l}\text { 1. Visceral obesity defined by cut-off } \\
\text { points derived from other ethnic groups } \\
\text { (Caucasian or Asian). } \\
\text { 2. BMI } \geq 30 \text { to define Obesity. }\end{array}$ & $\begin{array}{l}\text { 1. Use the Latin America cut-off point for waist circumference to identify visceral } \\
\text { obesity ( } \geq 94 \mathrm{~cm} \text { in men and } \geq 90 \mathrm{~cm} \text { in women ) } \\
\text { 2. Use a BMI } \geq 27.5 \text { to define obesity in the Venezuelan population }\end{array}$ \\
\hline $\begin{array}{l}\text { Diagnosis and } \\
\text { risk } \\
\text { identification }\end{array}$ & $\begin{array}{l}\text { 1. T2D or prediabetes screening is not } \\
\text { routinely done. } \\
\text { 2. OGTT is performed after a high-carb } \\
\text { breakfast. } \\
\text { 3. In the OGTT are solicited serial } \\
\text { measurements (every hour or half hour) } \\
\text { of plasma glucose and insulin and even } \\
\text { glycosuria. } \\
\text { 4. Measurements of plasma insulin for } \\
\text { diagnosis of dysglycemia and/or insulin } \\
\text { resistance. }\end{array}$ & $\begin{array}{l}\text { 1. Include the Latin America modified version of FINDRISK (mFR) as screening tool } \\
\text { to identify people who need blood testing (OGTT) to diagnose impaired glucose } \\
\text { regulation or occult T2D. Prediabetes and unknown diabetes is suspected by Lat mFR } \\
\text { score }>14 \text {. } \\
\text { 2. Recommend an OGTT with a } 75 \text { g glucose load and not after a "high carbo } \\
\text { breakfast". } \\
\text { 3. Educate physicians to request only fasting plasma glucose and the value } 2 \text {-h after } \\
75 \text {-g of oral anhydrous glucose. } \\
\text { 4. Do not use plasma insulin measurements to establish the state of glucose } \\
\text { homeostasis or insulin resistance. }\end{array}$ \\
\hline $\begin{array}{l}\text { Pharmacologic } \\
\text { treatment }\end{array}$ & $\begin{array}{l}\text { Metformin is used as "anti-obesity" drug } \\
\text { and in insulin-resistance states. }\end{array}$ & $\begin{array}{l}\text { Avoid prescribing metformin as an specific "anti-obesity" drug or in subjects with } \\
\text { normal glucose regulation. }\end{array}$ \\
\hline Obesity & $\begin{array}{l}\text { Consideration of obesity only as a } \\
\text { cosmetic problem. }\end{array}$ & $\begin{array}{l}\text { Consider obesity as a disease and regulate those individuals, professionals and } \\
\text { non-professionals who are treating obesity only from an aesthetic point of view. }\end{array}$ \\
\hline Bariatric surgery & $\begin{array}{l}\text { Offering bariatric surgery to subjects } \\
\text { who do not meet the requirement of BMI } \\
\text { or diabetic patients without obesity. }\end{array}$ & Recommend bariatric and metabolic surgery according to approved consensus criteria. \\
\hline $\begin{array}{l}\text { Other general } \\
\text { considerations }\end{array}$ & $\begin{array}{l}\text { 1. Possible heterogeneity in the gathering } \\
\text { and presentation of information from } \\
\text { each country. } \\
\text { 2. No specific goals for Prediabetes and } \\
\text { T2D in the main algorithm. }\end{array}$ & $\begin{array}{l}\text { 1. To standardize the information to be collected in each country in the process of } \\
\text { transculturization of tDNA. } \\
\text { 2. To specify control goals for prediabetes: No progression to T2D or biochemical } \\
\text { criteria (FBG }<100 \mathrm{mg}, 2 \text { h post } 75 \text { g oral glucose }<140 \mathrm{mg} / \mathrm{dL}, \mathrm{A} 1 \mathrm{c}<5.7 \% \text { ). } \\
\text { 3. To specify control goals for T2D: weight goals, blood } \\
\text { pressure }<140 / 80 \mathrm{mmHg}, \mathrm{FBG} 70-130 \mathrm{mg} / \mathrm{dL}, \mathrm{A} 1 \mathrm{c}<7 \% \text {, and } / \text { or LDL } \\
\text { cholesterol }<100 \mathrm{mg} / \mathrm{dL} \text {. }\end{array}$ \\
\hline
\end{tabular}




\section{Conclusions}

Prevention and appropriate treatment of prediabetes, T2D, and related or associated cardiovascular risk factors must be based on lifestyle changes that include an increase in physical activity and the correct implementation of MNT. Although there are clinical practice guidelines that can direct these interventions, they are not always easy to implement for their lack of portability and their failure to address the specific characteristics of the target population. The Venezuelan population, in particular, has unique epidemiological, cultural, physiological, ethnic, nutritional, pathological, and lifestyle characteristics, as well as a political, economic and social environment that is distinct and mostly unstable. All of these aspects of Venezuelan life must be considered when addressing the healthcare needs of its people, especially those needs related to food, dietary habits, and therapeutic lifestyle interventions that are so closely tied to genealogy and culture. After a group of international experts developed a diabetes-specific nutrition algorithm to facilitate and simplify the implementation of MNT for prediabetes and T2D, a local task force analyzed in detail the factors to be considered in the Venezuelan adaptation of the algorithm, which were described in this report. Recommendations from the task force are summarized in Table 9. The next steps will be to design simple and practical tools and programs to facilitate the implementation and validation of tDNA in Venezuela and to study the prevalence of cardiovascular risk factors and their relationship with the lifestyles unique to Venezuela.

\section{Acknowledgments}

We thank Juan Pablo González, Jendri Perez, Carlos Oribio, and Jose Miguel Gil for their help with data gathering.

\section{Disclosures}

Ramfis Nieto-Martínez has served as a board member for Abbott Nutrition, Sanofi-Aventis, Astra Zeneca, Bristol-Myers Squibb, Roche and Pfizer; has server as speaker of Abbott Nutrition, Sanofi-Aventis, Astra Zeneca, Bristol-Myers Squibb, GSK, Pfizer, Eli Lilly, MSD, Novartis and Merck; has received funding for travel and accommodations from Abbott Nutrition, Sanofi-Aventis, GSK, Pfizer, MSD, Novartis, Merck and Roche and has received a research grant from Novartis.

Maria Ines Marulanda has served as a board member for Abbott Nutrition, Astra Zeneca and Pfizer; has server as speaker of Abbott Nutrition, Astra Zeneca, Pfizer, Novartis, Roche and Bayer; has received funding for travel and accommodations from Abbott Nutrition, Sanofi-Aventis, Pfizer, Novartis, Boeringher Inghelheim, Astra-Zeneca, Bayer and Roche and has received a research grant from Novartis.

Osama Hamdy has received financial support as a consultant from Abbott Nutrition and as a speaker from Amylin/Eli Lilly and Abbott Nutrition.

Daniel Marante has served as a board member for Eli Lilly, Novartis, Sanofi-Aventis, Bristol-Myers Squibb and Abbott Nutrition; has server as speaker of Eli Lilly, Sanofi-Aventis, Novonordisk and Medtronic; and acted as independent medical advisor for Novonordisk from 2010 to 2011.

Albert Marchetti has received financial support for research and the development of educational materials from BMS, Abbott Nutrition, Takeda, and Eli Lilly. 
Refaat Hegazi is employed by Abbott Nutrition International; the information presented in this article is based on the best-known clinical evidence and is not affected by this financial relationship.

Jeffrey Mechanick has received financial support from Abbott Nutrition International for the development of educational presentations.

\section{Conflicts of Interest}

The authors declare no conflict of interest.

\section{References}

1. IDF (2011) International Diabetes Federation Diabetes Atlas. Diabetes Estimates Excel Tables. Available online: http://www.idf.org (accessed on 14 October 2012).

2. Escobedo, J.; Buitrón, L.V.; Velasco, M.F.; Ramírez, J.C.; Hernández, R.; Macchia, A.; Pellegrini, F.; Schargrodsky, H.; Boissonnet, C.; Champagne, B.M.; et al. High prevalence of diabetes and impaired fasting glucose in urban Latin America: The CARMELA Study. Diabet. Med. 2009, 26, 864-871.

3. Florez, H.; Silva, E.; Fernández, V.; Ryder, E.; Sulbarán, T.; Campos, G.; Calmón, G.; Clavel, E.; Castillo-Florez, S.; Goldberg, R. Prevalence and risk factors associated with the metabolic syndrome and dyslipidemia in White, Black, Amerindian and Mixed Hispanics in Zulia State, Venezuela. Diabetes Res. Clin. Pract. 2005, 69, 63-77.

4. González, J.P.; Nieto-Martínez, R.; Molina, T.; García, R.J.; Ugel, E.; Osuna, D.; Salazar, L. Prevalencia de síndrome metabólico, obesidad y alteración de la glucemia en ayunas en adultos del páramo del Estado Mérida, Venezuela (estudio VEMSOLS). Med. Int. 2012, 28, 262-267.

5. Duarte-Moreira, E.D., Jr.; Neves, R.C.; Nunes, Z.O.; de Almeida, M.C.; Mendes, A.B.; Fittipaldi, J.A.; Ablan, F.; Venezuelan Diabetes Investigators' Group. Glycemic control and its correlates in patients with diabetes in Venezuela: Results from a nationwide survey. Diabetes Res. Clin. Pract. 2010, 87, 407-414.

6. Mechanick, J.I.; Marchetti, A.E.; Apovian, C.; Benchimol, A.K.; Bisschop, P.H.; Bolio-Galvis, A.; Hegazi, R.A.; Jenkins, D.; Mendoza, E.; Sanz, M.L.; et al. Diabetes-specific nutrition algorithm: A transcultural program to optimize diabetes and prediabetes care. Curr. Diabetes Rep. 2012, 12, 180-194.

7. INE, Instituto Nacional de Estadísticas. República Bolivariana de Venezuela. Censo 2011. Available online: http://www.ine.gov.ve/ (accessed on 12 September 2012).

8. Guías ALAD Sobre el Diagnóstico, Control y Tratamiento de la Diabetes Mellitus Tipo 2 con Medicina Basada en Evidencia. Available online: http://issuu.com/alad-diabetes/docs/guias_alad 2013 (accessed on 12 February 2014).

9. OPS. Salud en la Américas. Organización Panamericana de la Salud; Publicación Científica y Técnica No. 622 II-Países: Washington, DC, USA, 2006; pp. 770-784.

10. Pan American Health Organization. Technical Reference Document on Non-communicable Disease Prevention and Control. July 2011. Available online: http://new.paho.org/hq/index.php? option $=$ com_docman\&task $=$ doc_view\&gid=14815\&Itemid $=($ accessed on 6 October 2012 $)$. 
11. Health in the Americas. Scientific and Technical Publication No. 636. 2012 Edition. Available online: http://health-equity.blogspot.com/2012/09/eq-paho-health-in-americas-2012-edition.html (accessed on 14 October 2012).

12. Prevention and Control of Non-Communicable Diseases. Report of the Secretary-General. Follow-Up to the Outcome of the Millennium Summit A/66/83. Available online: http://www. un.org/ga/search/view_doc.asp?symbol=A/66/83\&Lang=E (accessed on 1 September 2012).

13. WHO. World Health Statistics 2012, Part III: Global Health Indicators. Available online: http://www.who.int/gho (accessed on 2 September 2012).

14. Rodriguez, T.; Malvezzi, M.; Chatenoud, L.; Bosetti, C.; Levi, F.; Negri, E.; La Vecchia, C. Trends in mortality from coronary heart and cerebrovascular diseases in the Americas: 1970-2000. Heart 2006, 92, 453-460.

15. Ciruzzi, M.; Schargrodsky, H.; Pramparo, P.; Rivas Estany, E.; Rodriguez Naude, L.; de la Noval Garcia, R.; Gaxiola Cazarez, S.; Meaney, E.; Nass, A.; Finizola, B.; et al. Attributable risks for acute myocardial infarction in four countries of Latin America. Medicina 2003, 63, 697-703.

16. Lanas, F.; Avezum, A.; Bautista, L.E.; Diaz, R.; Luna, M.; Islam, S.; Yusuf, S. Risk factors for acute myocardial infarction in Latin America: The INTERHEART Latin American study. Circulation 2007, 115, 1067-1074.

17. Case, C.; Brito, S.; Palma, A.; Lares, M.; Pérez, E. Factores de riesgo asociados a diabetes mellitus tipo 2 en indios waraos del delta amacuro, Venezuela. Interciencia 2006, 31, 309-311.

18. Garcia-Araujo, M.; Semprún-Fereira, M.; Sulbarán, T.A.; Silva, E.; Calmón, G.; Campos, G. Nutritional and metabolic factors as risk factors for cardiovascular diseases in an adult population in the city of Maracibo, Estado Zulia, Venezuela. Investig. Clin. 2001, 42, $23-42$.

19. Ryder, E.; Hernández-Hernández, R.; Champagne, B.M.; Silva, H.; Vinueza, R.; Silva Ayçaguer, L.C.; Touboul, P.J.; Boissonnet, C.P.; Escobedo, J.; Pellegrini, F.; et al. Black Hispanics have a worse cardiovascular risk profile than mixed Hispanics in Venezuela. Investig. Clin. 2007, 48, 45-55.

20. Schargrodsky, H.; Hernández-Hernández, R.; Champagne, B.M.; Silva, H.; Vinueza, R.; Silva Ayçaguer, L.C.; Touboul, P.J.; Boissonnet, C.P.; Escobedo, J.; Pellegrini, F.; et al. CARMELA: Assessment of cardiovascular risk in seven Latin American cities. Am. J. Med. 2008, 121, 58-65.

21. Lee, I.M.; Shiroma, E.J.; Lobelo, F.; Puska, P.; Blair, S.N.; Katzmarzyk, P.T.; Lancet Physical Activity Series Working Group. Effect of physical inactivity on major non-communicable diseases worldwide: An analysis of burden of disease and life expectancy. Lancet 2012, 380, 219-229.

22. Hallal, P.C.; Andersen, L.B.; Bull, F.C.; Guthold, R.; Haskell, W.; Ekelund, U.; Lancet Physical Activity Series Working Group. Global physical activity levels: Surveillance progress, pitfalls, and prospects. Lancet 2012, 380, 247-257.

23. Granero, R.; Poni, E.; Sánchez, Z. Patrones de actividad física durante tiempo de ocio entre estudiantes del séptimo al noveno grado en el Estado Lara, Venezuela. Av. Cardiol. 2007, 27, 160-167. 
24. Brajkovich, I.; Arismendi, Z.; Benedetti, P.; Crocce, N.; Escudero, P.; Escauriza, M.; España, M.; González, R.; Khawan, R.; Márquez, M.; et al. Prevalencia de sobrepeso y obesidad en una población de Catia La Mar (Edo. Vargas) y Municipio Sucre Distrito Metropolitano de Caracas. Rev. Venezol. Endocrinol. Metab. 2006, 4, 32.

25. Brajkovich, I.; González, R.; Peña, N.; Suarez, M.; Terrones, O.; Crocce, N.; Rizquez, A.; Millán, A. Prevalencia de Síndrome Metabólico en una muestra poblacional del Estado Vargas. Noviembre 2005-Enero 2006 (Ambulatorio de Vía Eterna, Catia La Mar; Sector I, Parroquia Raúl Leoni. Estado Vargas). Rev. Venezol. Endocrinol. Metab. 2006, 4, 31.

26. Brajkovich, I.; Arismendi, Z.; Benedetti, P.; Escudero, P.; Escauriza, M.; España, M.; Khawan, R.; Marquez, M.; Megadja, M.; Millán, A.; et al. Prevalencia de síndrome metabólico en el Municipio Sucre, Estado Miranda, distrito metropolitano de Caracas. Rev. Venezol. Endocrinol. Metab. 2006, 4,31 .

27. De Oliveria, L.; García, E.; Torres, J.; Rivas, A. Prevalencia de síndrome metabólico en el sector Olivett. El Junquito. Rev. Venezol. Endocrinol. Metab. 2006, 4, 3.

28. García, R.S.; Roa, M.; Zavala, N.; Nuñez, R.; Alfieri, A.B.; Cubeddu, L.X.; Hoffman, I.S. Niveles de LDL-colesterol, HDL-colesterol y triglicéridos en una muestra poblacional de la Gran Caracas, distribuidos por sexo y por edad. Rev. Venezol. Endocrinol. Metab. 2006, 4, 27.

29. Lunar, L.; Serafin, M.; da Silva, R. Prevalencia del síndrome metabólico en Venezuela: El estudio sind-Met Venezuela. Rev. Venezol. Endocrinol. Metab. 2006, 4, 33.

30. Moya-Sifontes, M.; García-Avendaño, P.; Lucena, N.; Casañas, R.; Brito, P.; Rodríguez, A.; Flores, Z.; Cordero, R. Hipocinetismo: Un problema de salud entre jóvenes ucevistas? Rev. Fac. Med. 2006, 29, 74-79.

31. Pérez-Correa, N.G.; Moya-Sifontes, M.; Bauce, G.; García, P.; Cueva, E.; Peña, R.; Flores, Z. Patrones alimentarios y niveles de actividad física en estudiantes de la Universidad Central de Venezuela. Rev. Esp. Nutr. Comun. 2009, 15, 129-144.

32. Ruiz-Fernández, N.; Espinoza, M.; Barrios, E.; Reigosa, A. Factores cardiometabólicos en una comunidad de Valencia, Venezuela. Rev. Salud Públ. 2009, 11, 383-394.

33. Nieto-Martínez, R.; González, J.P.; Ugel, E. Estudio Venezolano de Síndrome Metabólico, Obesidad y Estilo de Vida (Estudio VEMSOLS). Unplublished work, 2013.

34. Hernández, R.; Chacón-Ramírez, L.A.; Hernández-Farazo, A.; Aguero, R.E.; Hernández-Faraco, G.; Armas-Hernández, M.J.; Armas-Padilla, M.C.; Guerrero-Puente, J. Estudio de la prevalencia de la hipertensión arterial en Barquisimeto, Venezuela. Bol. Méd. Postgrado 1994, 10, 1-11.

35. Granero, R.; Finizola, B.; Infante, E. Tendencias en hipertension arterial en el Estudio de la Salud Cardiovascular del Estado Lara (ESCEL), Venezuela 1987 y 1997. Av. Cardiol. 2004, 24, 85-89.

36. Nieto-Martínez, R.E.; González, J.P.; García, R.J.; Ugel, E.; Osuna, D.; Salazar, L. Prevalencia de hipertensión arterial y dislipidemias en adultos del páramo del Estado Mérida y su relación con obesidad. Resultados preliminares del estudio VEMSOLS. Av. Cardiol. 2011, 31, 193-200.

37. Becerra-Leal, A.V.; Lenin-Valery, A.; Arata-Bellabarba, G.; Velásquez-Maldonado, E.M. Prevalencia de síndrome metabólico en la población urbana de Mucuchíes, Mérida-Venezuela. Rev. Venez. Endocrinol. Metab. 2009, 7, 16-22. 
38. Uzcátegui Pinto, E.; Baptista, T.; Carrizo, E.; Valeri, L.; Uzcátegui, L.R.; Gómez Pérez, R. Prevalencia del síndrome metabólico en sujetos de la población general, área metropolitana, Municipio Libertador de la ciudad de Mérida, Venezuela 2006. Rev. Venez. Endocrinol. Metab. 2009, 7, 40.

39. Sulbaran, T.; Silva, E.; Calmón, G.; Vegas, A. Epidemiologic aspects of arterial hypertension in Maracaibo, Venezuela. J. Hum. Hypertens. 2000, 14, S6-S9.

40. Sirit, Y.; Acero, C.; Bellorin, M.; Portillo, R. Metabolic syndrome and other factors cardiovascular risk in workers of a plant of vinyl polychloride. Rev. Salud Publ. 2008, 10, 239-249.

41. Campos, G.; Ryder, E.; Diez-Ewald, M.; Rivero, F.; Fernández, V.; Raleigh, X.; Arocha-Piñango, C.L.; y Grupo para el Estudio del Fibrinógeno como Factor de Riesgo Coronario en Venezuela (FRICVE). Prevalencia de obesidad e hiperinsulinemia en una población aparentemente sana de Maracaibo, Venezuela y su relación con las concentraciones de lípidos y lipoproteínas del suero. Investig. Clin. 2003, 44, 15.

42. Astrup, A.; Dyerberg, J.; Selleck, M.; Stender, S. Nutrition transition and its relationship to the development of obesity and related chronic diseases. Obes. Rev. 2008, 9, 48-52.

43. Joshi, S.R.; Mohan, V.; Joshi, S.S.; Mechanick, J.I.; Marchetti, A. Transcultural diabetes nutrition therapy algorithm: The Asian Indian application. Curr. Diabetes Rep. 2012, 12, 204-212.

44. INE. Instituto Nacional de Estadística. Available online: http://www.noticias24.com/venezuela/ noticia/8401/ine-presento-los-resultados-de-la-encuesta-de-seguimiento-al-consumo-de-alimentos -desde-2003-a-2010 (accessed on 12 September 2012).

45. Montilva, M.; Berné, Y.; Papale, J.; García-Casal, M.N.; Ontiveros, Y.; Durán, L. Perfil de alimentación y nutrición de mujeres en edad fértil de un Municipio del Centroccidente de Venezuela. Anal. Venez. Nutr. 2010, 23, 67-74.

46. Calanche Morales, J.B. Influencias culturales en el régimen alimentario del venezolano. Anal. Venez. Nutr. 2009, 22, 32-40.

47. Suárez, M.M.; Bosch, V.; Aliaga, C.; García, N. La empanada en Venezuela: Importancia social y nutricional. Anal. Venez. Nutr. 2010, 23 88-99.

48. Lago-Moneo, J. El Consumo de Comida Rápida. Situación en el Mundo y Acercamiento Autonómico. Available online: http://www.abc.es/gestordocumental/uploads/Sociedad/comidarapida.pdf (accessed on 13 December 2013)

49. BCV. IV Encuesta Nacional de Presupuestos Familiares y Hábitos Alimenticios del Venezolano: Principales Resultados. Available online: http://iies.faces.ula.ve/IV_ENPF/enpf.htm (accessed on 12 September 2012).

50. Marin, M.; Vivas de Vegas, J. Elaboración de una estrategia para manejo nutricional de diabetes lipo 2 basada en tablas de Índice Glicémico. Rev. Venezol. Endocrinol. Metab. 2006, 4, 24.

51. Izquierdo, M.; Oráa, E.; de los Ríos, V.; Drayer, R.; Urbina, D. Índice glucémico e insulinémico de alimentos ricos en carbohidratos. Rev. Venezol. Endocrinol. Metab. 2006, 4, 25.

52. Herrera, N.; Reif, B.; Suárez, A.; Malo, M.; Castillo, H.A.; Ayala, A.; Melkon, R.; Negrín, S. El Alcohol y las Políticas Públicas en Venezuela; Organización Panamericana de la Salud: Caracas, Venezuela, 2009.

53. Seale, J.P.; Seale, J.D.; Alvarado, M.; Vogel, R.L.; Terry, N.E. Prevalence of problem drinking in a Venezuelan native American population. Alcohol Alcohol. 2002, 37, 198-204. 
54. WHO. United Nations, Data Range 1990-2006; World Health Organization: Geneva, Switzerland, 2011.

55. Negretti de Bratter, V.E.; Bratter, P.; Oliver, W.; Alvarez, N. Study of the Trace Element Status and the Dietary Intake of Mineral and Trace Elements in Relation to the Gastric Cancer Incidence in Tachira, Venezuela. Metal Ions in Biology and Medicine; Collery, P., Negretti de Bratter, V.E., Khassanova, L., Etienne, J.-C., Eds.; John Libbet Eurotext: Paris, France, 1998; pp. 557-565.

56. Hoffmann, I.S.; Cubeddu, L.X. Increased blood pressure reactivity to dietary salt in patients with the metabolic syndrome. J. Hum. Hypertens. 2007, 21, 438-444.

57. Aschner, P.; Buendía, R.; Brajkovich, I.; Gonzalez, A.; Figueredo, R.; Juarez, X.E.; Uriza, F.; Gomez, A.M.; Ponte, C.I. Determination of the cutoff point for waist circumference that establishes the presence of abdominal obesity in Latin American men and women. Diabetes Res. Clin. Pract. 2011, 93, 243-247.

58. Romero-Corral, A.; Somers, V.K.; Sierra-Johnson, J.; Thomas, R.J.; Collazo-Clavell, M.L.; Korinek, J.; Allison, T.G.; Batsis, J.A.; Sert-Kuniyoshi, F.H.; Lopez-Jimenez, F. Accuracy of body mass index in diagnosing obesity in the adult general population. Int. J. Obes. 2008, 32, 959-966.

59. Nieto-Martínez, R.; Pérez, Y.; Suárez, M.A.; Ugel, E. A BMI of 27.5 can improve the detection of obesity in a Venezuelan population. Diabetes 2013, 62, A750.

60. Molero-Conejo, E.; Morales, L.M.; Fernández, V.; Raleigh, X.; Gómez, M.E.; Semprún-Fereira, M.; Campos, G.; Ryder, E. Lean adolescents with increased risk for metabolic syndrome. Arch. Latioam Nutr. 2003, 53, 39-46.

61. Zambrano, M.; Fernández, E.; López, M.; Rangel, A.; de Romero, P.; Fernández, V.; Marina Morales, L.; Molero-Conejo, E.; Connell, L.; Raleigh, X.; et al. Gly482Ser polymorphism of the coactivator-1alpha of the activated receptor of peroxisome gamma proliferation in individuals from Maracaibo, Venezuela. Investig. Clin. 2009, 50, 285-294.

62. Almarza, J.; Arráiz, N.; Bermúdez, V.; Prieto, C.; Escalona, C. Polimorfismos del gen UCP-3 en individuos con síndrome metabólico del Municipio Maracaibo-Venezuela. Rev. Venezol. Endocrinol. Metab. 2012, 10, 65-71.

63. Ryder, E.; Gómez, M.E.; Fernández, V.; Campos, G.; Morales, L.M.; Valbuena, H.; Raleigh, X. Glucose/insulin response to a glucose overload in subjects at risk for type 2 diabetes. Investig. Clin. 2001, 42, 269-281.

64. Ryder, E.; Gómez, M.E.; Fernández, V.; Campos, G.; Morales, L.M.; Valbuena, H.; Raleigh, X. Presence of impaired insulin secretion and insulin resistance in normoglycemic male subjects with family history of type 2 diabetes. Diabetes Res. Clin. Pract. 2003, 60, 95-103.

65. López, J.E.; Urbaneja, H. Tolerancia a la glucosa e insulinemia en hermanos asintomáticos de pacientes diabéticos tipo 2. Gac. Méd. Caracas 2006, 114, 305-317.

66. Lindstrom, J.; Tuomilehto, J. The diabetes risk score: A practical tool to predict type 2 diabetes risk. Diabetes Care 2003, 26, 725-731.

67. Aschner, P.; Nieto-Martínez, R.; Marín, A.; Ríos, M. Validation of the Findrisk score as a screening tool for people with impaired glucose regulation in Latin America using modified score points for waist circumference according to the validated regional cutoff values for abdominal obesity. Minerva Endocrinol. 2012, 37, 114. 
68. Chiuve, S.E.; McCullough, M.L.; Sacks, F.M.; Rimm, E.B. Healthy lifestyle factors in primary prevention of coronary heart disease among men. Circulation 2006, 114, 160-167.

69. Reeves, M.J.; Rafferty, A.P. Healthy lifestyle characteristics among adults in the United States 2000. Arch. Intern. Med. 2005, 165, 854-857.

70. Tuomilehto, J.; Lindström, J.; Eriksson, J.G.; Valle, T.T.; Hämäläinen, H.; Ilanne-Parikka, P.; Keinänen-Kiukaanniemi, S.; Laakso, M.; Louheranta, A.; Rastas, M.; et al. Prevention of type 2 diabetes mellitus by changes in lifestyle among subjects with impaired glucose tolerance. $N$. Engl. J. Med. 2001, 344, 1343-1350.

71. Knowler, W.C.; Fowler, S.E.; Hamman, R.F.; Christophi, C.A.; Hoffman, H.J.; Brenneman, A.T.; Brown-Friday, J.O.; Goldberg, R.; Venditti, E.; Nathan, D.M.; et al. 10-Year follow-up of diabetes incidence and weight loss in the Diabetes Prevention Program Outcomes Study. Lancet 2009, 374, 1677-1686.

72. Liu, S.; Serdula, M.; Janket, S.J.; Cook, N.R.; Sesso, H.D.; Willett, W.C.; Manson, J.E.; Buring, J.E. A prospective study of fruit and vegetable intake and the risk of type 2 diabetes in women. Diabetes Care 2004, 27, 2993-2996.

73. Villegas, R.; Shu, X.O.; Gao, Y.T.; Yang, G.; Elasy, T.; Li, H.; Zheng, W. Vegetable but not fruit consumption reduces the risk of type 2 diabetes in Chinese women. J. Nutr. 2008, 138, 574-580.

74. Priebe, M.G.; van Binsbergen, J.J.; de Vos, R.; Vonk, R.J. Whole grain foods for the prevention of type 2 diabetes mellitus. Cochrane Database Syst. Rev. 2008, 23, CD006061.

75. Baliunas, D.O.; Taylor, B.J.; Irving, H.; Roerecke, M.; Patra, J.; Mohapatra, S.; Rehm, J. Alcohol as a risk factor for type 2 diabetes: A systematic review and meta-analysis. Diabetes Care 2009, $32,2123-2132$.

76. Thomas, D.; Elliott, E.J. Low glycaemic index, or low glycaemic load, diets for diabetes mellitus. Cochrane Database Syst. Rev. 2009, 21, CD006296.

77. Matusheski, N.V.; Bidel, S.; Tuomilehto, J. Coffee and Type 2 Diabetes Risk, Chapter 8 in Coffee Emerging Health Effects and Disease Prevention; Chu, Y.F., Ed.; John Wiley \& Sons: Ames, IA, USA, 2012; pp. 141-179.

78. Salas-Salvadó, J.; Bulló, M.; Babio, N.; Martínez-González, M.Á.; Ibarrola-Jurado, N.; Basora, J.; Estruch, R.; Covas, M.I.; Corella, D.; Arós, F.; et al. Reduction in the incidence of type 2 diabetes with the Mediterranean diet: Results of the PREDIMED-Reus nutrition intervention randomized trial. Diabetes Care 2011, 34, 14-19.

79. Estruch, R.; Ros, E.; Salas-Salvadó, J.E.A. Primary Prevention of Cardiovascular Disease with a Mediterranean Diet. N. Engl. J. Med. 2013, 368, 1279-1290. Available online: http://www. nejm.org/doi/full/10.1056/NEJMoa1200303 (accessed on 14 March 2013).

80. Serra-Majem, L.; Roman, B.; Estruch, R. Scientific evidence of interventions using the Mediterranean diet: A systematic review. Nutr. Rev. 2006, 64, S27-S47.

81. Giugliano, D.; Esposito, K. Mediterranean diet and metabolic diseases. Curr. Opin. Lipidol. 2008, $19,63-68$.

82. Willett, W.C.; Sacks, F.; Trichopoulou, A.; Drescher, G.; Ferro-Luzzi, A.; Helsing, E.; Trichopoulos, D. Mediterranean diet pyramid: A cultural model for healthy eating. Am. J. Clin. Nutr. 1995, 61, 1402S-1406S. 
83. Franz, M.J.; Monk, A.; Barry, B.E.A. Effectiveness of medical nutrition therapy provided by dietitians in the management of non-insulin-dependent diabetes mellitus: a randomized, controlled clinical trial. J. Am. Diet. Assoc. 1995, 95, 1009-1017.

84. Hensrud, D.D. Converting Knowledge to Action, Chapter 7. Mayo Clinic on Healthy Weight, 1st ed.; Kensington Publishing Corporation: New York, NY, USA, 2000; pp. 77-104.

85. ADA. Standards of medical care in diabetes 2013. Diabetes Care 2013, 36, S11-S66.

86. Gonzalez-Campoy, J.M.; St Jeor, S.T.; Castorino, K.; Ebrahim, A.; Hurley, D.; Jovanovic, L.; Mechanick, J.I.; Petak, S.M.; Yu, Y.H.; Harris, K.A; et al. Clinical practice guidelines for healthy eating for the prevention and treatment of metabolic and endocrine diseases in adults: Cosponsored by the American Association of Clinical Endocrinologists/the American College of Endocrinology and the Obesity Society. Endocr. Pract. 2013, 19, 1-82.

87. Fenadiabetes. Guía Práctica en Diabetes Mellitus; Gruber, E., Ablan, F., Arocha, J.I., Eds.; Smart Marketing: Caracas, CA, USA, 2012; p. 277.

88. Lichtenstein, A.H.; Appel, L.J.; Brands, M.; Carnethon, M.; Daniels, S.; Franch, H.A.; Franklin, B.; Kris-Etherton, P.; Harris, W.S.; Howard, B.; et al. Diet and lifestyle recommendations revision 2006: A scientific statement from the American Heart Association Nutrition Committee. Circulation 2006, 114, 82-96.

89. Sacks, F.M.; Svetkey, L.P.; Vollmer, M.S.E.A.; DASH-sodium collaborative group. Effects on blood pressure of reduced dietary sodium and the dietary approaches to stop hypertension (DASH) diet. N. Engl. Med. 2001, 344, 3-10.

90. Bantle, J.P.; Wylie-Rosett, J.; Albright, A.L.; Apovian, C.M.; Clark, N.G.; Franz, M.J.; Hoogwerf, B.J.; Lichtenstein, A.H.; Mayer-Davis, E.; Mooradian, A.D.; et al. Nutrition recommendations and interventions for diabetes: A position statement of the American Diabetes Association. Diabetes Care 2008, 31, S61-S78.

91. Elia, M.; Ceriello, A.; Laube, H.; Sinclair, A.J.; Engfer, M.; Stratton, R.J. Enteral nutritional support and use of diabetes-specific formulas for patients with diabetes: A systematic review and meta-analysis. Diabetes Care 2005, 28, 2267-2279.

92. Livesey, G.; Taylor, R.; Hulshof, T.; Howlett, J. Glycemic response and health-A systematic review and meta-analysis: Relations between dietary glycemic properties and health outcomes. Am. J. Clin. Nutr. 2008, 87, 258S-268S.

93. Hamdy, O.; Zwiefelhofer, D. Weight management using a meal replacement strategy in type 2 diabetes. Curr. Diabetes Rep. 2010, 10, 159-164.

94. Wadden, T.A.; Neiberg, R.H.; Wing, R.R.; Clark, J.M.; Delahanty, L.M.; Hill, J.O.; Krakoff, J.; Otto, A.; Ryan, D.H.; Vitolins, M.Z.; et al. Four-year weight losses in the Look AHEAD study: Factors associated with long-term success. Obesity 2011, 19, 1987-1998.

95. Pozzilli, P.; Leslie, R.D.; Chan, J.; de Fronzo, R.; Monnier, L.; Raz, I.; Del Prato, S. The A1C and $\mathrm{ABCD}$ of glycaemia management in type 2 diabetes: A physician's personalized approach. Diabetes Metab. Res. Rev. 2010, 26, 239-244.

96. Nieto-Martínez, R. Actividad física en la prevención y tratamiento de la diabetes. Rev. Venezol. Endocrinol. Metab. 2010, 8, 40-45. 
97. Florez, H.J.; Stepenka, V.; Castillo-Florez, S.; Rivas, Y.; Casal, J.; Ryder, E.; Silva, E.; Maestre, G.; Oropeza, L. Lifestyle intervention improves global cardiovascular health in latinos with prediabetes in Maracaibo, Venezuela. Circulation 2012, 125, AP162.

98. US Department of Health and Human Services. 2008 Physical Activity Guidelines for Americans. 2008. Available online: http://www.health.gov/paguidelines/guidelines/summary.aspx (accessed on 22 June 2011).

99. Leyba, J.L.; Aulestia, S.N.; Llopis, S.N. Laparoscopic Roux-en-Y gastric bypass versus laparoscopic sleeve gastrectomy for the treatment of morbid obesity. A prospective study of 117 patients. Obes. Surg. 2011, 21, 212-216.

100. International Diabetes Federation. Bariatric Surgical Procedures and Interventions in the Treatment of Obese Patients with Type 2 Iabetes: A Position Statement from the International Diabetes Federation Taskforce on Epidemiology and Prevention. Available online: http://www.idf.org/webdata/docs/IDF-Position-Statement-Bariatric-Surgery.pdf (accessed on 3 March 2013).

101. Navarrete, A.S.; Leyba, J.; Navarrete, L.L.S.; García Caballero, M.; Sánchez, N.; Pulgar, V.; Vivas, A. Roux-en-Y gastric bypass for treatment of patients with DM type 2 and BMI of 30 to $35 \mathrm{~kg} / \mathrm{m}^{2}$. Nutr. Hosp. 2012, 27, 1160-1165.

102. ASMBS. Bariatric surgery in class I obesity (body mass index $30-35 \mathrm{~kg} / \mathrm{m}^{2}$ ). Surg. Obes. Relat. Dis. 2013, 9, 18.

103. Handelsman, Y.; Mechanick, J.I.; Blonde, L.E.A. American association of clinical endocrinologists medical guidelines for clinical practice for developing a diabetes mellitus comprehensive care plan. Endocr. Pract. 2011, 17, 1-53.

104. Mechanick, J.; Garber, A.J.; Handelsman, Y.; Garvey, W.T. American Association of Clinical Endocrinologists' position statement on obesity and obesity medicine. Endocr. Pract. 2012, 18, 642-648.

105. Balkau, B.; Charles, M.A. Comment on the provisional report from the WHO consultation. European Group for the Study of Insulin Resistance (EGIR). Diabet. Med. 1999, 16, 442-443.

106. García, R.S.; Hoffmann, I.S. Utilizacion de la metformina en diferentes centros de salud del área metropolitana de Caracas. Rev. Venezol. Endocrinol. Metab. 2006, 4, 41-41.

107. Knowler, W.C.; Barrett-Connor, E.; Fowler, S.E.; Hamman, R.F.; Lachin, J.M.; Walker, E.A.; Nathan, D.M.; Diabetes Prevention Program Research Group. Reduction in the incidence of type 2 diabetes with lifestyle intervention or metformin. N. Engl. J. Med. 2002, 346, 393-403.

(C) 2014 by the authors; licensee MDPI, Basel, Switzerland. This article is an open access article distributed under the terms and conditions of the Creative Commons Attribution license (http://creativecommons.org/licenses/by/3.0/). 